\title{
Determination of Henry's constant, the dissociation constant, and the buffer capacity of the bicarbonate system in ruminal fluid
}

\author{
Katharina T. Hille, ${ }^{*}$ Stefan K. Hetz, $†$ Julia Rosendahl, ${ }^{*}$ Hannah-Sophie Braun, ${ }^{*}$ Robert Pieper,‡ \\ and Friederike Stumpff*1 \\ *Institute of Veterinary Physiology, Faculty of Veterinary Medicine, Freie Universität Berlin, 14163 Berlin, Germany \\ †Department of Animal Physiology, Systems Neurobiology and Neural Computation, Humboldt-Universität zu Berlin (Germany), 10115 Berlin, \\ Germany \\ ‡lnstitute of Animal Nutrition, Faculty of Veterinary Medicine, Freie Universität Berlin, 14195 Berlin, Germany
}

\section{ABSTRACT}

Despite the clinical importance of ruminal acidosis, ruminal buffering continues to be poorly understood. In particular, the constants for the dissociation of $\mathrm{H}_{2} \mathrm{CO}_{3}$ and the solubility of $\mathrm{CO}_{2}$ (Henry's constant) have never been stringently determined for ruminal fluid. The $\mathrm{pH}$ was measured in parallel directly in the rumen and the reticulum in vivo, and in samples obtained via aspiration from 10 fistulated cows on hay- or concentrate-based diets. The equilibrium constants of the bicarbonate system were measured at $38^{\circ} \mathrm{C}$ both using the Astrup technique and a newly developed method with titration at 2 levels of partial pressure of $\mathrm{CO}_{2}\left(\mathrm{pCO}_{2} ; 4.75\right.$ and $\left.94.98 \mathrm{kPa}\right)$, yielding mean values of $0.234 \pm 0.005 \mathrm{mmol} \cdot \mathrm{L}^{-1} \cdot \mathrm{kPa}^{-1}$ and $6.11 \pm 0.02$ for Henry's constant and the dissociation constant, respectively $(\mathrm{n} / \mathrm{n}=31 / 10)$. Both reticular $\mathrm{pH}$ and the $\mathrm{pH}$ of samples measured after removal were more alkalic than those measured in vivo in the rumen (by $\Delta \mathrm{pH}$ $=0.87 \pm 0.04$ and $0.26 \pm 0.04)$. The amount of acid or base required to shift the $\mathrm{pH}$ of ruminal samples to 6.4 or 5.8 (base excess) differed between the 2 feeding groups. Experimental results are compared with the mathematical predictions of an open 2-buffer Henderson-Hasselbalch equilibrium model. Because $\mathrm{pCO}_{2}$ has pronounced effects on ruminal $\mathrm{pH}$ and can decrease rapidly in samples removed from the rumen, introduction of a generally accepted protocol for determining the acid-base status of ruminal fluid with standard levels of $\mathrm{pCO}_{2}$ and measurement of base excess in addition to $\mathrm{pH}$ should be considered.

Key words: rumen, bicarbonate, dissociation constant, Henry's constant

Received February 20, 2015.

Accepted September 7, 2015.

${ }^{1}$ Corresponding author: stumpff@zedat.fu-berlin.de

\section{INTRODUCTION}

Acute and subacute ruminal acidosis is a fermentational disorder afflicting ruminants with symptoms can negatively affect milk fat content, feed intake, and milk yield. The condition affects some 10 to $40 \%$ of dairy cows at least once in a lifetime and is associated with a low ruminal $\mathrm{pH}$, inflammation of the ruminal epithelium, and loss of ruminal barrier function (Enemark, 2008; Plaizier et al., 2012). Efflux of pathogens and their toxins into the portal circulation follows (Plaizier et al., 2008). Symptoms include systemic immunological complications with lameness, liver abscesses, and dehydration due to ruminal bloating that can be lethal (Kleen et al., 2003; Plaizier et al., 2008).

Early diagnosis is crucial because animals can recover after shifting dietary balance away from starches and toward physically effective neutral detergent fiber to stimulate chewing activity and the production of salivary buffers such as $\mathrm{NaHCO}_{3}$ (Allen, 1997; Mertens, 1997; Yang and Beauchemin, 2006; Zebeli et al., 2012; Maulfair et al., 2013). Although correlations exist between SARA and parameters such as a drop in milk fat or a rise renal net acid excretion, these criteria have yet to replace ruminal $\mathrm{pH}$ as the leading diagnostic tool (Enemark, 2008). Investigators have suggested various $\mathrm{pH}$ thresholds ranging from $\mathrm{pH}<5$ to $\mathrm{pH}<5.2$ for the acute form of the disease, whereas a range of $\mathrm{pH}$ $<5.5$ to $\mathrm{pH}<6.0$ or even higher has been suggested for SARA (Duffield et al., 2004; Krause and Oetzel, 2006; Plaizier et al., 2008). Depending on the study, these thresholds can refer to measurements at a certain time point, the daily means, or the nadir of a continuous measurement. Even if the procedure is identical, the $\mathrm{pH}$ ranges given are clearly too large to satisfy the clinician in the field who has to make a decision on whether dietary intervention is necessary or not ( $\mathrm{Li}$ et al., 2012). Accordingly, various other parameters for identifying animals or herds at risk are being discussed, which include the concentrations of ruminal acetic, propionic, 
isobutyric, butyric, and caproic acids, lactate, and ammonia (Krause and Oetzel, 2005; Bramley et al., 2008).

A parameter that is curiously missing from this rising list is the partial pressure of $\mathrm{CO}_{2}\left(\mathbf{p C O}_{2}\right)$ in the rumen, which is known to vary between 36.7 and $66.5 \mathrm{kPa}$ (Turner and Hodgetts, 1955; McArthur and Miltimore, 1961; Kölling, 1974; Counotte et al., 1979) and can be expected to drop sharply after removal of a sample, in particular when pressure drops during aspiration. Spurious changes of this nature can thus be expected to add to the poor outcomes of attempts at identifying precise thresholds for the onset of ruminal acidosis.

When trying to assess the magnitude of a variation in $\mathrm{pCO}_{2}$ on ruminal $\mathrm{pH}$, another omission emerges: the only available value for the dissociation constant ( $\mathbf{p} \mathbf{K}_{\text {app }}$ ) of $\mathrm{H}_{2} \mathrm{CO}_{3}$ in ruminal fluid was determined decades ago at an inappropriate temperature $\left(25^{\circ} \mathrm{C}\right.$; Turner and Hodgetts, 1955) and using a value for the solubility of $\mathrm{CO}_{2}(\alpha)$ that was obtained in 1917 in aqueous solution (Van Slyke and Cullen, 1917). In one of the very few more recent detailed studies of the issue (Counotte et al., 1979), the authors concluded that "bicarbonate will not play an important role as a base, until the $\mathrm{pH}$ in the rumen is 6.25 or lower." Made in the context of an otherwise exemplary study, this statement suggests that the authors are erroneously treating the rumen as a closed buffer system in which buffer capacity is maximal around the pK value of the bicarbonate system.

Several studies since have clarified that due to absorption of $\mathrm{CO}_{2}$ from the rumen and regular eructation, the bicarbonate system of the rumen has to be regarded as an open buffer system comparable to that of the blood (Allen, 1997; Kohn and Dunlap, 1998). Protons react with $\mathrm{HCO}_{3}{ }^{-}$to form $\mathrm{H}_{2} \mathrm{O}$ and $\mathrm{CO}_{2}\left(\mathrm{H}^{+}+\mathrm{HCO}_{3}{ }^{-} \Leftrightarrow\right.$ $\mathrm{H}_{2} \mathrm{CO}_{3} \Leftrightarrow \mathrm{H}_{2} \mathrm{O}+\mathrm{CO}_{2}$ ). Because $\mathrm{CO}_{2}$ does not accumulate in the system but escapes, the bicarbonate system buffers strongly at neutral $\mathrm{pH}$ and beyond. A further problem that emerges when trying to understand ruminal buffering is that equations solving the underlying mixed SCFA- $\mathrm{HCO}_{3}{ }^{-}$buffer problem are lacking in the literature. These have been now been derived and are given in the Appendix of this study.

A major question that remains is whether the values for Henry's constant $(\alpha)$ and the dissociation constant (pK) that were determined for blood plasma (Andersen, 1962; Segel, 1976) can be applied to ruminal fluid. Both $\alpha$ and the pK of the bicarbonate system are known to vary not only with the osmolarity and the temperature, but also with protein content and various other parameters (Heisler, 1986). Given that the effect of short-chain fatty acids (SCFA) on both constants has never been studied, a rigorous determination of both constants for fluid from the rumen appears overdue. In the current study of bovine ruminal solution, Henry's constant $\alpha$ and the pK of $\mathrm{H}_{2} \mathrm{CO}_{3}$ are determined using a classical variation of the Astrup technique. These results are confirmed by those obtained via a novel titration method developed in the course of this study. Finally, the concept of base excess was adapted to allow a better evaluation of the acid-base status of ruminal fluid.

\section{MATERIALS AND METHODS}

\section{Care and Use of Animals}

All experiments were performed in accordance with German laws for the protection of animals [permits L0016/09 (Berlin) and 33.12-42502-04-14/1501 (Braunschweig)].

\section{Animals and Sampling}

A first set of samples was obtained from 2 fistulated cows (h1 and h2) that were kept in tethered housing on straw at the faculty of veterinary medicine in Berlin. Initially, the animals received a hay-only diet at 0730 and $1500 \mathrm{~h}$ and water ad libitum. These animals will be referred to as hay/silage-fed in what follows because the animals received small amounts of grass silage in addition to hay toward the end of the experimental period.

The 2 hay/silage-fed cows were sampled twice weekly for a period of $3 \mathrm{wk}$. On experimental days, samples were taken immediately before the morning meal and approximately $4 \mathrm{~h}$ afterward $(0700$ and $1100 \mathrm{~h})$ so that, in total, 12 samples were obtained from each of the 2 cows.

Before sampling, a 3-way stopcock was fitted to the fistula plug, allowing the measurement of intraruminal pressure using a differential pressure measurement device (Testo 510, Testo, Letzkirch, Germany). Negative basal values of $-0.71 \pm 0.06 \mathrm{kPa}(\mathrm{n}=24)$ inside the rumen were observed versus barometric pressure outside, which alternated with short pressure bouts above the barometric level reflecting eructation.

After opening the fistula, intraruminal $\mathrm{pH}$ was measured approximately 10 to $15 \mathrm{~cm}$ below liquid level using a portable $\mathrm{pH}$ meter (pH-Meter 1140, Mettler Toledo, Gießen, Germany) calibrated at $37^{\circ} \mathrm{C}$ with standard buffer ( $\mathrm{pH} 4$ and 7) immediately before use. Subsequently, approximately $200 \mathrm{~mL}$ of ruminal fluid were obtained after insertion of an oro-ruminal sampling device into the rumen through the ruminal fistula. The $\mathrm{pH}$ of this sample was also recorded. Fluid aliquots were immediately frozen in liquid nitrogen to stop fermentation processes and stored at $-20^{\circ} \mathrm{C}$. 
For comparison, one sample each was obtained from 8 fistulated cows in late lactation (Federal Research Institute for Animal Health, Braunschweig, Germany), referred to as concentrate/silage-fed in what follows. The animals were kept in housing with free stalls on a performance-oriented diet (60\% maize and 40\% grass silage based on DM content) and received water ad libitum. Each cow additionally received $4 \mathrm{~kg}$ of concentrate feeding per day via an automated feeding system with radio frequency technology for identification of individual animals. In addition to sampling of ruminal fluid through the fistula, these animals were equipped with an electronic $\mathrm{pH}$ sensor placed in the ruminoreticulum to measure $\mathrm{pH}$ and temperature (smaXtec Animal Care $\mathrm{GmbH}$, Graz, Austria), calibrated as suggested by the manufacturer. Data obtained during the hour before sampling were averaged. Otherwise, sampling and measurement of ruminal $\mathrm{pH}$ was performed as described above.

\section{Measurement of SCFA Concentrations}

Analysis of SCFA was performed by gas chromatography as described previously, yielding values for acetic, propionic, i-butyric, n-butyric, i-valeric, n-valeric, and total SCFA (Pieper et al., 2012).

\section{Determination of Henry's Constant $\alpha$, the $p K_{a p p}$, and the Buffer Capacity $\beta_{N B}$ of Ruminal Fluid}

The solubility of $\mathrm{CO}_{2}(\alpha)$ in ruminal fluid and the apparent dissociation constant $\mathrm{pK}_{\mathrm{app}}$ of ruminal fluid were determined using 2 separate approaches: a classical variation of the Astrup technique (Heisler, 1986) and a novel titration technique.

In brief, each sample of ruminal fluid was thawed and centrifuged $(3,200 \times g, 5 \mathrm{~min}$, ambient temperature $)$ to minimize feed residues and subsequently divided into aliquots that were equilibrated with 4 different partial pressures of $\mathrm{pCO}_{2}$ to allow determination of $\alpha$ and $\mathrm{pK}_{\text {app }}$ as described below. Equilibration of ruminal fluid was achieved with a humidified $\mathrm{CO}_{2} / \mathrm{N}_{2}$ gas mixture via the rotating flask method (Heisler, 1986) in a water bath at $38^{\circ} \mathrm{C}$ for at least 60 min (Figure 1a). The $\mathrm{CO}_{2}: \mathrm{N}_{2}$ mixtures were generated using a gas mixing pump (Woesthoff 1M301/a-F, Woesthoff, Bochum, Germany). Partial pressure of $\mathrm{CO}_{2}$ was calculated by multiplying the fraction of $\mathrm{CO}_{2}$ in the gas mixture with ambient pressure corrected for humidity at $38^{\circ} \mathrm{C}$ using the Magnus equation (Terblanche et al., 2008).

Determination of Total Carbonate Concentration $\left[\mathrm{CO}_{2}\right]_{\text {tot }}$. Determination of $\alpha$ and $\mathrm{pK}_{\text {app }}$ according to the Astrup technique requires determination of
$\left[\mathrm{CO}_{2}\right]_{\text {tot }}$, which is the sum of bicarbonate and dissolved $\mathrm{CO}_{2}$. For this purpose, a Foxbox $\mathrm{CO}_{2}$ measuring system (Sable Systems, Las Vegas, NV) was equipped with a reaction vessel for the sample. An internal gas pump continuously flushed gas from the external vessel to an infrared $\mathrm{CO}_{2}$ sensor. A long thin tube from the vessel to the outside served to keep the pressure within the system at ambient levels (see Figure 1b).

The measuring device was calibrated on a daily basis both before and after the measurements by injecting $0.5 \mathrm{~mL}$ of a $100 \mathrm{mmol} \cdot \mathrm{L}^{-1} \mathrm{NaHCO}_{3}$ solution through an injection port into the reaction vessel. After acidification with a small amount of $1 \mathrm{~mol} \cdot \mathrm{L}^{-1} \mathrm{H}_{2} \mathrm{SO}_{4}$ to $\mathrm{pH}<4$, the $\left[\mathrm{HCO}_{3}{ }^{-}\right]$in the sample was protonated to form $\mathrm{CO}_{2}$ gas (Cameron, 1971; Heisler, 1986), which was then stripped off the sample by the continuous flow of the carrier gas through the system and flushed to the Foxbox $\mathrm{CO}_{2}$ sensor. On average, the coefficient of variation 4 consecutive measurements was $5.8 \%$. The system was aerated with ambient air if $\mathrm{CO}_{2}$ content exceeded $2 \%$ in the carrier gas.

For measurements, $0.5 \mathrm{~mL}$ of the equilibrated ruminal fluid sample was slowly aspired from the flask (Figure 1a) using a gas-tight syringe. Care was taken to avoid formation of gas bubbles due to negative pressure. After injection into the reaction vessel and acidification (1 mol. $\left.\mathrm{L}^{-1} \mathrm{H}_{2} \mathrm{SO}_{4}\right)$, all $\left[\mathrm{HCO}_{3}{ }^{-}\right]$in the sample was converted into gaseous $\mathrm{CO}_{2}$, which was driven off the solution by the carrier gas flowing through the system and measured with the $\mathrm{CO}_{2}$ sensor of the Foxbox. Foxbox analog outputs were digitized with a resolution of 12 bits and transferred to a personal computer at 0.2 samples $\cdot \mathrm{s}^{-1}$ and immediately analyzed (TurboLab software, MDZ Bührer \& Partner, Münster, Germany). Steady state values of $\mathrm{CO}_{2}$ were assumed to have been achieved if the difference between of 2 consecutive averages of $60 \mathrm{~s}$ was less than $0.2 \%$ of the maximal range of the measurement. Afterward, residual fluid from the reaction vessel was sucked off and the measurement was repeated twice. If the difference between 3 of these iterations exceeded $5 \%$, a fourth sample was analyzed.

Determination of the Solubility $\alpha$ of $\mathrm{CO}_{2}$. The total carbon dioxide concentration $\left[\mathrm{CO}_{2}\right]_{\text {tot }}$ is given by the bicarbonate concentration in the sample $\left[\mathrm{HCO}_{3}{ }^{-}\right]$ and the partial pressure of $\mathrm{CO}_{2}\left(\mathrm{pCO}_{2}\right)$ according to

$$
\left[\mathrm{CO}_{2}\right]_{\mathrm{tot}}=\left[\mathrm{HCO}_{3}^{-}\right]+\alpha \cdot \mathrm{pCO}_{2} .
$$

For $\mathrm{pH}$ values $<4$, the $\left[\mathrm{HCO}_{3}{ }^{-}\right]$in the sample is negligible, so that

$$
\alpha \sim\left[\mathrm{CO}_{2}\right]_{\text {tot }}^{\mathrm{HCO}_{3}^{-}} \text {free } / \mathrm{pCO}_{2}
$$


for $\mathrm{pH}<4$. Accordingly, aliquots of ruminal fluid were acidified to $\mathrm{pH}<4$ before the measurement to drive out preexisting $\mathrm{HCO}_{3}{ }^{-}$. The acidified samples were then equilibrated with a known $\mathrm{pCO}_{2}$ and $\left[\mathrm{CO}_{2}\right]_{\mathrm{tot}}^{\mathrm{HCO}_{3}^{-}}$free measured using the Foxbox system as described above. Values for $\alpha$ were obtained for each individual sample of ruminal fluid.

Determination of $p K_{a p p}$ of the Bicarbonate System. The apparent dissociation constant $\mathrm{pK}_{\text {app }}$ can be calculated from the Henderson-Hasselbalch equation defined as

$$
\begin{aligned}
\mathrm{pH} & =\mathrm{pK}_{\text {app }}+\log _{10} \frac{\left[\mathrm{HCO}_{3}^{-}\right]}{\alpha \cdot \mathrm{pCO}_{2}} \\
& =\mathrm{pK}_{\text {app }}+\log 10 \frac{\left[\mathrm{CO}_{2}\right]_{\mathrm{tot}}-\alpha \cdot \mathrm{pCO}_{2}}{\alpha \cdot \mathrm{pCO}_{2}} .
\end{aligned}
$$

Once $\alpha$ has been determined, the $\mathrm{pK}_{\text {app }}$ of each sample could be determined using this relationship by measuring the $\mathrm{pH}$ and the $\left[\mathrm{CO}_{2}\right]_{\text {tot }}$ of the sample. The $\mathrm{pK}_{\text {app }}$ was obtained for each sample of ruminal fluid at each $\mathrm{pCO}_{2}$ using equation [3]. Values of $\mathrm{pK}_{\mathrm{app}}$ from the 4 ali-

a

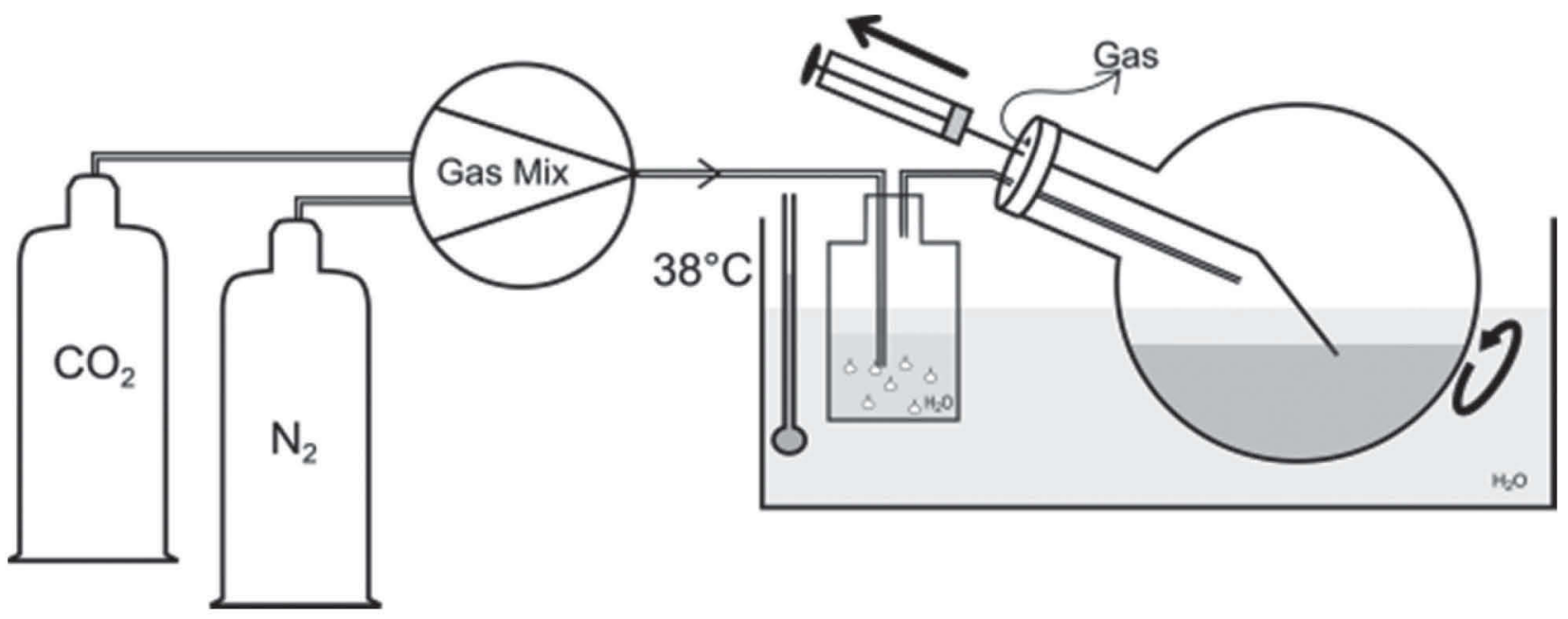

b

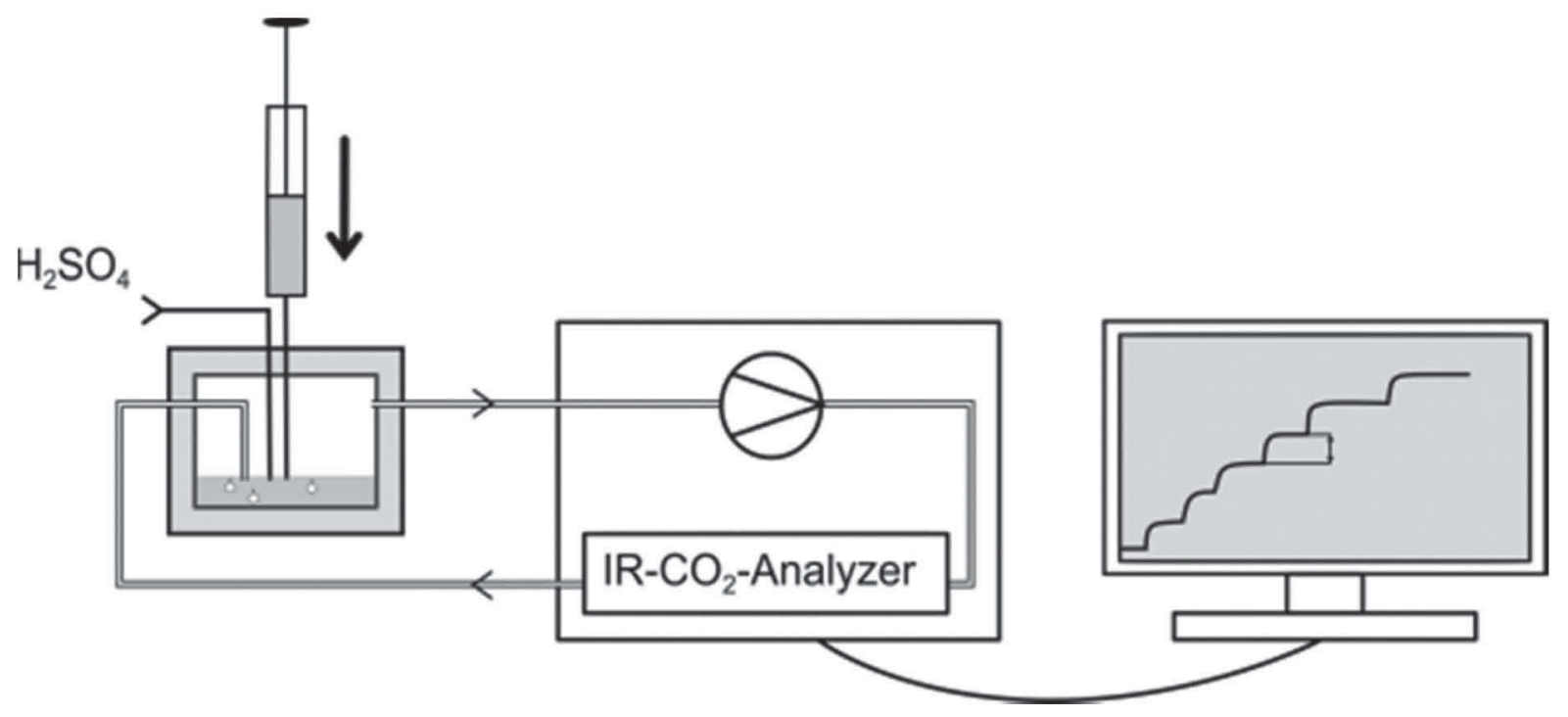

Figure 1. Experimental setup used for measurements with the Astrup technique: (a) the partial pressure of $\mathrm{CO}_{2}$ was set to defined values using a gas mixing pump. Equilibration to this partial pressure of $\mathrm{CO}_{2}\left(\mathrm{pCO}_{2}\right)$ occurred at $38^{\circ} \mathrm{C}$ for at least 60 min; the solution was stirred via rotation of the flask to produce a thin film of the fluid on the wall of the flask, maximizing the surface area for gas exchange (Heisler, 1986). (b) After equilibration, a sample was introduced into the reaction vessel of the measuring device and acidified to $\mathrm{pH}^{2} 4$ with $\mathrm{H}_{2} \mathrm{SO}_{4}$ to protonate the $\mathrm{HCO}_{3}{ }^{-}$in the sample. After dissociation and dehydration of $\mathrm{H}_{2} \mathrm{CO}_{3}$, the resulting $\mathrm{CO}_{2}$ was flushed out of the reaction vessel to a CO sensor, driven by a continuous stream of carrier gas through the system. The system was aerated with ambient air if $\mathrm{CO}_{2} \mathrm{content}$ exceeded $2 \%$ in the carrier gas. The amount of $\mathrm{CO}_{2}$ added per measurement was recorded by a personal computer (TurboLab Software, MDZ Bührer \& Partner, Münster, Germany). 
quots were averaged to yield one mean value for each ruminal sample.

Determination of the Nonbicarbonate Buffer Capacity $\beta_{N B}$ by Titration with $\mathrm{CO}_{2}$. When a solution is equilibrated with gaseous $\mathrm{CO}_{2}$, protons originating from the hydration and dissociation of $\mathrm{CO}_{2}$ are not just in equilibrium with preexisting $\mathrm{HCO}_{3}{ }^{-}$, but are also bound by nonbicarbonate buffering anions (e.g., SCFA). This changes the concentration of the protonated complex $\left(\Delta\left[\mathrm{H}^{+}\right.\right.$-Buffer $\left.]\right)$, so that the $\mathrm{HCO}_{3}{ }^{-}$concentration will rise with the concentration of physically solved $\mathrm{CO}_{2}\left(\left[\mathrm{CO}_{2}\right]\right)$ according to

$$
\begin{aligned}
& {\left[\mathrm{H}_{2} \mathrm{O}\right]+\left[\mathrm{CO}_{2}\right]+\left[\text { Buffer }^{-}\right] } \\
\Leftrightarrow & \Delta\left[\mathrm{HCO}_{3}^{-}\right]+\Delta\left[\mathrm{H}^{+}-\text {Buffer }^{-}\right]+\left[\mathrm{H}^{+}\right] .
\end{aligned}
$$

Within the physiological $\mathrm{pH}$ range of 5 to 8 , the concentration of free protons $\left(\left[\mathrm{H}^{+}\right]\right)$is very small and the $\Delta\left[\mathrm{HCO}_{3}{ }^{-}\right]$that is formed from $\mathrm{CO}_{2}$ essentially reflects the amount of protons buffered by the nonbicarbonate buffers. This allows an assessment of the buffer capacity of nonbicarbonate anions, $\beta_{\mathrm{BN}}$, which can be determined from the change in $\mathrm{pH}(\Delta \mathrm{pH})$ and the change in bicarbonate concentration $\left(\Delta\left[\mathrm{HCO}_{3}{ }^{-}\right]\right)$according to (Heisler, 1986):

$$
\beta_{\mathrm{NB}}=\frac{\Delta\left[\mathrm{OH}^{-}\right]}{\Delta \mathrm{pH}}=-\frac{\Delta\left[\mathrm{H}^{+}\right]}{\Delta \mathrm{pH}}=-\frac{\Delta\left[\mathrm{HCO}_{3}^{-}\right]}{\Delta \mathrm{pH}} .
$$

To gain an estimate of $\beta_{\mathrm{NB}}$, aliquots of the various samples were equilibrated with 4 different values of $\mathrm{pCO}_{2}$ (ranging from 2.0 to $86.3 \mathrm{kPa}$ ) with subsequent determination of $\mathrm{pH}$ and $\left[\mathrm{CO}_{2}\right]_{\mathrm{tot}}$, from which $\left[\mathrm{HCO}_{3}{ }^{-}\right]$ could be determined using equation [1]. After plotting $\left[\mathrm{HCO}_{3}{ }^{-}\right]$against the $\mathrm{pH}$ in a Davenport diagram (Davenport, 1974), the buffer capacity $\beta_{\mathrm{NB}}$ of the sample was determined from the slope of the linear regression (equation [5]).

Determination of $\alpha$ and $p K_{a p p}$ and the Base Excess from Titration Curves at Differing $\mathrm{pCO}_{2}$. A second approach was used to validate the results obtained from the Astrup technique. The method uses the fact that the buffer capacity of various components of a multi-buffer system are additive (Heisler, 1986), so that the total buffer capacity $\beta_{\text {tot }}$ of a system is given by the sum of the buffer capacity of all nonbicarbonate buffers $\left(\Sigma \beta_{\mathrm{NB}}\right)$ and the contribution of the bicarbonate system $\left(\beta_{\text {bicarbonate }}\right)$ according to

$$
\beta_{\text {tot }}=\sum \beta_{\mathrm{NB}}+\beta_{\text {bicarbonate }} .
$$

If $\beta_{\text {tot }}$ of the solution is measured by simple titration over a range of $\mathrm{pH}$ values at 2 different $\mathrm{pCO}_{2}$, the re- sulting curves can be subtracted from each other so that the nonbicarbonate buffers $\left(\Sigma \beta_{\mathrm{NB}}\right)$ cancel out of the resulting difference function

$$
\begin{aligned}
\Delta \beta \text { tot } & =\left(\sum \beta_{\mathrm{NB}}+\beta_{\text {bicarbonate }(1)}\right)-\left(\sum \beta_{\mathrm{NB}}+\beta_{\text {bicarbonate }(2)}\right) \\
& =\beta_{\text {bicarbonate(1) }}-\beta_{\text {bicarbonate }(2) .}
\end{aligned}
$$

According to Heisler (1986),

$$
\beta_{\text {bicarbonate }}=\frac{\partial\left[\mathrm{HCO}_{3}^{-}\right]}{\partial \mathrm{pH}}=\frac{1}{\log _{10}(e)} \cdot\left[\mathrm{HCO}_{3}^{-}\right]=2.302 \cdot\left[\mathrm{HCO}_{3}^{-}\right]
$$

and

$$
\left[\mathrm{HCO}_{3}^{-}\right]=\alpha \cdot \mathrm{pCO}_{2} \cdot 10^{(\mathrm{pH}-\mathrm{pK})}
$$

We get $\Delta \beta_{\text {tot }}$ as a function of $\mathrm{pH}$ :

$$
\Delta \beta_{\text {tot }}(\mathrm{pH})=2.302 \cdot \alpha \cdot \Delta \mathrm{pCO}_{2} \cdot 10^{(\mathrm{pH}-\mathrm{pK})},
$$

where $\Delta \mathrm{pCO}_{2}$ is the difference between the 2 partial pressures used in the measurements. If $\Delta \beta_{\text {tot }}(\mathrm{pH})$ is measured for several different $\mathrm{pH}$, the resulting curve can be fitted to equation [8] to yield values for $\alpha$ and $\mathrm{pK}_{\text {app}}$.

Experimental Procedure. For these measurements, aliquots of $20 \mathrm{~mL}$ of ruminal fluid were kept at $38^{\circ} \mathrm{C}$ and equilibrated with humidified gas containing either $100 \% \mathrm{CO}_{2}$ or carbogen gas $\left(95 \% \mathrm{O}_{2}, 5 \% \mathrm{CO}_{2}\right)$. After subtraction of the vapor pressure of $\mathrm{H}_{2} \mathrm{O}$ at $38^{\circ} \mathrm{C}(\sim 6.3$ $\mathrm{kPa}$ ), these conditions yield absolute pressure values of $\approx 94.98$ and $\approx 4.75 \mathrm{kPa} \mathrm{CO}_{2}$, respectively. The $\mathrm{HCl}$ $\left(1 \mathrm{mmol} \cdot \mathrm{L}^{-1}\right)$ or $\mathrm{NaOH}\left(1 \mathrm{mmol} \cdot \mathrm{L}^{-1}\right)$ were added in steps of 100 and $250 \mu \mathrm{mol}$, respectively. The $\mathrm{pH}$ was measured for each titration step. Total buffer capacity was determined by dividing the $\Delta \mathrm{pH}$ observed over 3 titration steps by the change in added acid or base $(\approx \Delta[\mathrm{HCl}]$ or $\approx-\Delta[\mathrm{NaOH}])$, correcting for dilution by the added amount. This value was assigned to the middle $\mathrm{pH}$ value of the respective triplet. In this manner, buffer capacity was determined over the entire $\mathrm{pH}$ range and 2 curves $\beta_{\text {tot }}\left(\mathrm{pH}, 94.98 \mathrm{kPa} \mathrm{CO}_{2}\right)$ and $\beta_{\text {tot }}$ $(\mathrm{pH}, 4.75 \mathrm{kPa} \mathrm{CO}$ ) were obtained.

After interpolation of the data along the $\mathrm{pH}$ axis in steps of $\Delta \mathrm{pH}=0.01$ and alignment along the $\mathrm{pH}$ axis, the 2 curves were subtracted to yield $\Delta \beta_{\text {tot }}(\mathrm{pH}$, $\Delta \mathrm{pCO}_{2}$ ), plotted over $\mathrm{pH}$, and fitted to equation [8] yielding Henry's constant $\alpha$ and the $\mathrm{pK}_{\text {app }}$ of the bicarbonate system for the sample investigated (all using SigmaPlot for Windows, Version 11.0, Systat Software Inc., San Jose, CA). In the fitting process, an addition- 
al variable was introduced into the fitting equation by subtraction from the measured $\mathrm{pH}$ to allow an estimate of the inaccuracy of the calibration of the $\mathrm{pH}$ meter, which was found to deviate from the theoretically expected value by a mean of $-0.06 \pm 0.02 \mathrm{pH}$ units.

\section{Determination of the Base Excess}

In analogy to the concept established for systemic acid-base physiology, the concept of base excess was used. For the present purpose, the base excess (BE) was defined as the amount of acid required to reach $\mathrm{pH}$ values of 6.4 or 5.8 in the ruminal sample studied (referred to as $\mathrm{BE}_{6.4}$ and $\mathrm{BE}_{5.8}$, respectively). This value depends on both the initial $\mathrm{pH}$ of the sample and on the amount of (unprotonated) buffer in the $\mathrm{pH}$ range of the measurement. Accordingly, the base excess of a sample with a total concentration of $100 \mathrm{mmol} \cdot \mathrm{L}^{-1}$ SCFA and an initial $\mathrm{pH}$ of 5 will be negative, as the addition of a base is required to adjust the $\mathrm{pH}$ to the desired level. Conversely, that of a sample with the same total concentration of SCFA but an initial $\mathrm{pH}$ of 7 will be positive. In ruminal samples, other buffers than SCFA can be expected to contribute.

In practice, the $\mathrm{BE}$ was determined from the titration data using $100 \% \mathrm{CO}_{2}$-equilibrated ruminal fluid (or $94.98 \mathrm{kPa} \mathrm{CO} \mathrm{CO}_{2}$ ) via linear interpolation between the data points around $\mathrm{pH} 6.4$ and 5.8, respectively. Here, as in all other parts of the study, results were corrected for the effect of dilution due to the addition of added acid or base.

\section{Evaluation of Data and Statistics}

Data were fitted to functions and compared statistically using SigmaPlot for Windows, Version 11.0, Systat Software Inc., and tested for significance using the Wilcoxon signed-rank test. Testing for correlation was performed using the Pearson product moment correlation (SigmaStat) for normally distributed data and the Spearman rank order correlation for not normally distributed data.

Results are presented as means \pm standard error. The number of experimental animals is designated by $\mathrm{N}$; the number of samples obtained as $\mathrm{n}$.

\section{RESULTS}

\section{Measurements of the $\mathrm{pH}$ in the Rumen, the Reticulum, and of Ruminal Samples in Vitro}

The ruminal $\mathrm{pH}$ of all animals studied was measured both directly through the fistula and in samples directly after aspiration through the rumen. The $\mathrm{pH}$ of these aliquots was found to be significantly higher than that measured directly in the rumen by an average of $0.26 \pm$ 0.04 units $(P<0.001, \mathrm{~N} / \mathrm{n}=18 / 32)$. In the following, only the directly measured values will be discussed.

The ruminal $\mathrm{pH}$ of the hay/silage-fed animals was $6.55 \pm 0.05(6.47 \pm 0.07$ for animal $\mathrm{h} 1$, and $6.64 \pm 0.09$ for animal $\mathrm{h} 2 ; P=0.078, \mathrm{n} / \mathrm{n}=24 / 2$ ). In each animal, the $\mathrm{pH}$ measured before feeding was significantly higher than the value measured afterward $(P=0.007)$.

The ruminal $\mathrm{pH}$ measured in concentrate/silage-fed cows was significantly lower $(5.52 \pm 0.04, \mathrm{n} / \mathrm{n}=8 / 8$; $P<0.001)$ than those of the hay/silage-fed animals. Mean reticular $\mathrm{pH}$ as measured by an electronic $\mathrm{pH}$ measuring bolus scattered around a mean that was 6.39 \pm 0.10 , significantly higher than values measured in the rumen $(P<0.001, \mathrm{n} / \mathrm{n}=8 / 8)$ and without any correlation to the $\mathrm{pH}$ measured directly in the rumen $\left(r^{2}=0.0004\right)$. This discrepancy may reflect the higher concentration of salivary buffers in this part of the forestomachs.

\section{Effect of $\mathrm{pCO}_{2}$ on the $\mathrm{pH}$ and on the Bicarbonate Concentration $\left[\mathrm{HCO}_{3}{ }^{-}\right]$}

When aliquots were equilibrated at defined $\mathrm{pCO}_{2}$ $\left[100 \% \mathrm{CO}_{2}(\approx 94.98 \mathrm{kPa})\right.$ and $\left.5 \% \mathrm{CO}_{2}(\approx 4.75 \mathrm{kPa})\right]$, mean $\mathrm{pH}$ was $6.40 \pm 0.03$ at $95 \mathrm{kPa} \mathrm{CO}_{2}$ and $7.63 \pm$ 0.04 at $4.7 \mathrm{kPa} \mathrm{CO}_{2}(\mathrm{~N} / \mathrm{n}=2 / 12)$ for the hay/silagefed cows. These values differed significantly from each other and from those measured in samples from cows fed a concentrate/silage diet (both $P<0.001$ ), where $\mathrm{pH}$ values of $5.58 \pm 0.05\left(95 \mathrm{kPa} \mathrm{CO}_{2}\right)$ and $5.85 \pm 0.12$ $\left(4.7 \mathrm{CO}_{2}\right)$ were observed $(P=0.008, \mathrm{~N} / \mathrm{n}=8 / 8)$.

To determine the effect of $\mathrm{pCO}_{2}$ on $\left[\mathrm{HCO}_{3}{ }^{-}\right]$, aliquots of each ruminal sample were equilibrated with 4 different values of $\mathrm{pCO}_{2}$ ranging randomly from 2 to $86 \mathrm{kPa}$. After determination of $\left[\mathrm{CO}_{2}\right]_{\text {tot }}$ and $\alpha$ as described in the Materials and Methods section, $\left[\mathrm{HCO}_{3}{ }^{-}\right]$could be calculated from equation [1]. The resulting pairs of $\mathrm{pH}$ and $\mathrm{HCO}_{3}{ }^{-}$are plotted in a Davenport diagram (Figure 2 for hay/silage-fed cows, Figure 3 for concentrate/ silage-fed cows).

In 3 samples, $\mathrm{HCO}_{3}{ }^{-}$decreased unexpectedly with rising $\mathrm{pCO}_{2}$. This may reflect either experimental error or release of nonvolatile $\mathrm{H}^{+}$ions that neutralize existing $\mathrm{HCO}_{3}{ }^{-}$in the sample (Heisler, 1986), possibly due to ongoing fermentation. Despite these 3 outliers, it can clearly be seen that rising levels of $\mathrm{pCO}_{2}$ within the physiological range can be expected to have considerable effect on the measured $\mathrm{pH}$ of a sample.

\section{Relationship Between Buffer Capacity and pH}

In the $\mathrm{pH}$ range studied, over $99 \%$ of the protons formed after solution of $\mathrm{CO}_{2}$ are bound to buffering 
anions, and thus, the slopes of the linear regressions between each quadruplet of data points in the Davenport diagrams (Figures 2 and 3 ) give an estimate of the nonbicarbonate buffer capacity $\beta_{\mathrm{NB}}=\left(\Delta\left[\mathrm{HCO}_{3}^{-}\right] /-\Delta \mathrm{pH}\right)$ of each sample. Nonbicarbonate buffer capacity depended primarily on the $\mathrm{pH}$ at which the measurement was performed, which in turn primarily related to the $\mathrm{pCO}_{2}$. No influence of time after feeding $(P=0.62)$ or of the individual cow $(P=0.62)$ studied was detectable, although a tendency was found for higher buffer capacity in the concentrate/silage-fed animals $(P=$ $0.07)$.

To assess the effect of $\mathrm{pH}$ on total buffer capacity over a range from $\sim 3$ to $\sim 8$, equilibrated samples were titrated using $\mathrm{HCl}$ and $\mathrm{NaOH}$ (see Figure 4a). Both at a $\mathrm{pCO}_{2}$ of 4.7 and $95 \mathrm{kPa}$, buffer capacity reached a local maximum at $\mathrm{pH} \sim 4.8$, reflecting the significant contribution of SCFA to total buffering power. Because buffer capacities are additive, interpolation and subtrac- tion of the curves at differing $\mathrm{pCO}_{2}$ yield the isolated contribution of the bicarbonate system to total buffer capacity (Figure 4b). By fitting these difference curves to equation [8], it was possible to determine $\mathrm{pK}_{\text {app }}$ and $\alpha$ of the bicarbonate system for each ruminal sample (titration method).

\section{Determination of $\alpha$ and $p K_{a p p}$ of the Bicarbonate System via the Astrup and the Titration Technique}

Using the Astrup technique with direct determination of $\left[\mathrm{CO}_{2}\right]_{\text {tot }}$, the solubility of $\mathrm{CO}_{2}(\alpha)$ in ruminal fluid was found to be $0.244 \pm 0.01 \mathrm{mmol} \cdot \mathrm{L}^{-1} \cdot \mathrm{kPa}^{-1}$ $(\mathrm{N} / \mathrm{n}=10 / 31)$. Solubility did not differ in the various feeding groups $(P=0.43)$, was not influenced by the time after feeding $(P=0.9)$, and showed no correlation to the SCFA concentration (Pearson coefficient $P>$ $0.05)$.

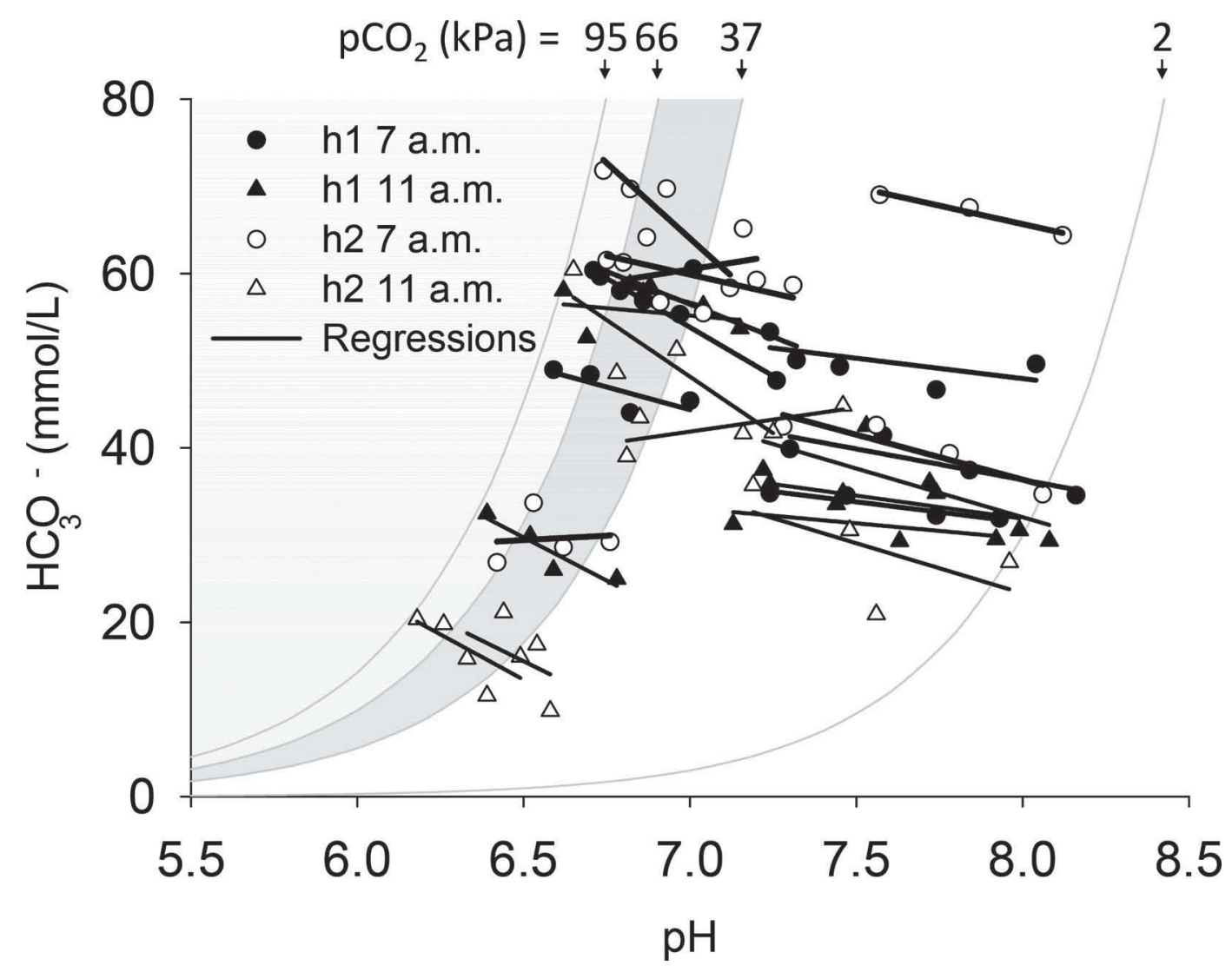

Figure 2. Davenport diagram showing a plot of the $\mathrm{pH}$ measured against the $\mathrm{HCO}_{3}{ }^{-}$concentration for samples taken from 2 hay/silage-fed cows (h1, h2). Samples were divided into 4 aliquots and equilibrated with 4 different values of partial pressure of $\mathrm{CO}_{2}\left(\mathrm{pCO}_{2}\right)$. The $\mathrm{pH}$ and the $\left[\mathrm{HCO}_{3}{ }^{-}\right]$of each of the 4 equilibrated samples were determined (Figure 1 and Materials and Methods section), plotted against each other, and fitted by linear regression. Because in the $\mathrm{pH}$ range studied, protons freed by the dissociation of $\mathrm{CO}_{2}$ are almost completely absorbed by the nonbicarbonate buffers of the system, the absolute value of the slope of this regression reflects the nonbicarbonate buffer capacity, $\beta_{\mathrm{NB}} \approx$ $-\Delta\left[\mathrm{HCO}_{3}^{-}\right] / \Delta \mathrm{pH}$, of each ruminal sample. The curved lines in the figure represent isobars of $95,66,37$, and $2 \mathrm{kPa}^{-}$of $\mathrm{CO}_{2}$ and were calculated using equation [3] and the corresponding $\mathrm{pK}_{\mathrm{app}}$. The gray area corresponds to the physiological range of ruminal $\mathrm{pCO}_{2}$ from 37 to $66 \mathrm{kPa}$. 
Using curve fitting after titration as described above, a value of $\alpha=0.223 \pm 0.003 \mathrm{mmol} \cdot \mathrm{L}^{-1} \cdot \mathrm{kPa}^{-1}$ was obtained for the hay/silage-fed animals $(\mathrm{N} / \mathrm{n}=2 / 24)$ and $0.232 \pm 0.012 \mathrm{mmol} \cdot \mathrm{L}^{-1} \cdot \mathrm{kPa}^{-1}$ for the concentrate/ silage-fed animals $(\mathrm{N} / \mathrm{n}=8 / 8)$. No difference emerged between the feeding groups $(P=0.7)$ or versus the values for $\alpha$ measured with the Astrup technique $(P=$ 0.152).

A mean dissociation constant $\mathrm{pK}_{\text {app }}$ of $6.21 \pm 0.03$ $(\mathrm{N} / \mathrm{n}=10 / 32)$ of all animals studied was found using the Astrup technique. Again, no significant difference emerged between hay/silage- and concentrate/silagefed animals $(P=0.3)$, and no correlation was found between the $\mathrm{pK}_{\text {app }}$ and the feeding regimen $(P=0.18)$, the time after feeding $(P=0.6)$, or the SCFA concentration in the sample $(P=0.6)$. The values obtained for $\mathrm{pK}_{\text {app }}$ using the titration method $(6.05 \pm 0.01$ for hay/silage-fed animals and $5.97 \pm 0.05$ for concentrate/ silage-fed animals) were slightly, but significantly, lower than those obtained with the Astrup technique $(P<$ $0.001)$ but again did not differ among each other $(P=$ $0.7)$.

In conjunction and using 2 independent methods, values of $\alpha=0.234 \pm 0.005 \mathrm{mmol} \cdot \mathrm{L}^{-1} \cdot \mathrm{kPa}^{-1}$ and $\mathrm{pK}_{\text {app }}$
$=6.11 \pm 0.02 ; \mathrm{n} / \mathrm{n}=31 / 10)$ were obtained for ruminal fluid, essentially identical to those reported for plasma (Andersen, 1962; Segel, 1976).

\section{Determination of the SCFA Concentration from the Titration Curves}

In an attempt to estimate the SCFA concentration ( $\left.[\mathrm{SCFA}]_{\mathrm{fit}}\right)$ from the buffer curves, the titration curves were fitted by the equation

$$
\begin{aligned}
\beta_{\text {tot }}(\mathrm{pH})= & \left.2.302 \cdot \alpha \cdot \mathrm{pCO}_{2} \cdot 10^{(\mathrm{pH}-\mathrm{d}-\mathrm{pK} \text { app }}\right) \\
& +2.302 \cdot \frac{[\mathrm{SCFA}]_{\mathrm{fit}}}{2+10^{(\mathrm{pH}-\mathrm{d}-\mathrm{pK})}+10^{(\mathrm{pK}-(\mathrm{pH}-\mathrm{d}))}},
\end{aligned}
$$

where $\mathrm{pK}_{\mathrm{SCFA}} \approx 4.76$ and $\mathrm{d}$ is the inaccuracy of the calibration of the $\mathrm{pH}$ meter.

For the hay/silage-fed animals, a mean value for the variable $[\mathrm{SCFA}]_{\mathrm{fit}}$ in this equation of $81 \pm 4 \mathrm{mmol} \cdot \mathrm{L}^{-1}$ was obtained. This value is in surprisingly good agreement with the mean of the total concentration of SCFA, $[\mathrm{SCFA}]_{\text {measured, }}$, as determined by gas chromatography ( $80 \pm 2 \mathrm{mmol} \cdot \mathrm{L}^{-1}$, hay/silage-fed cows).

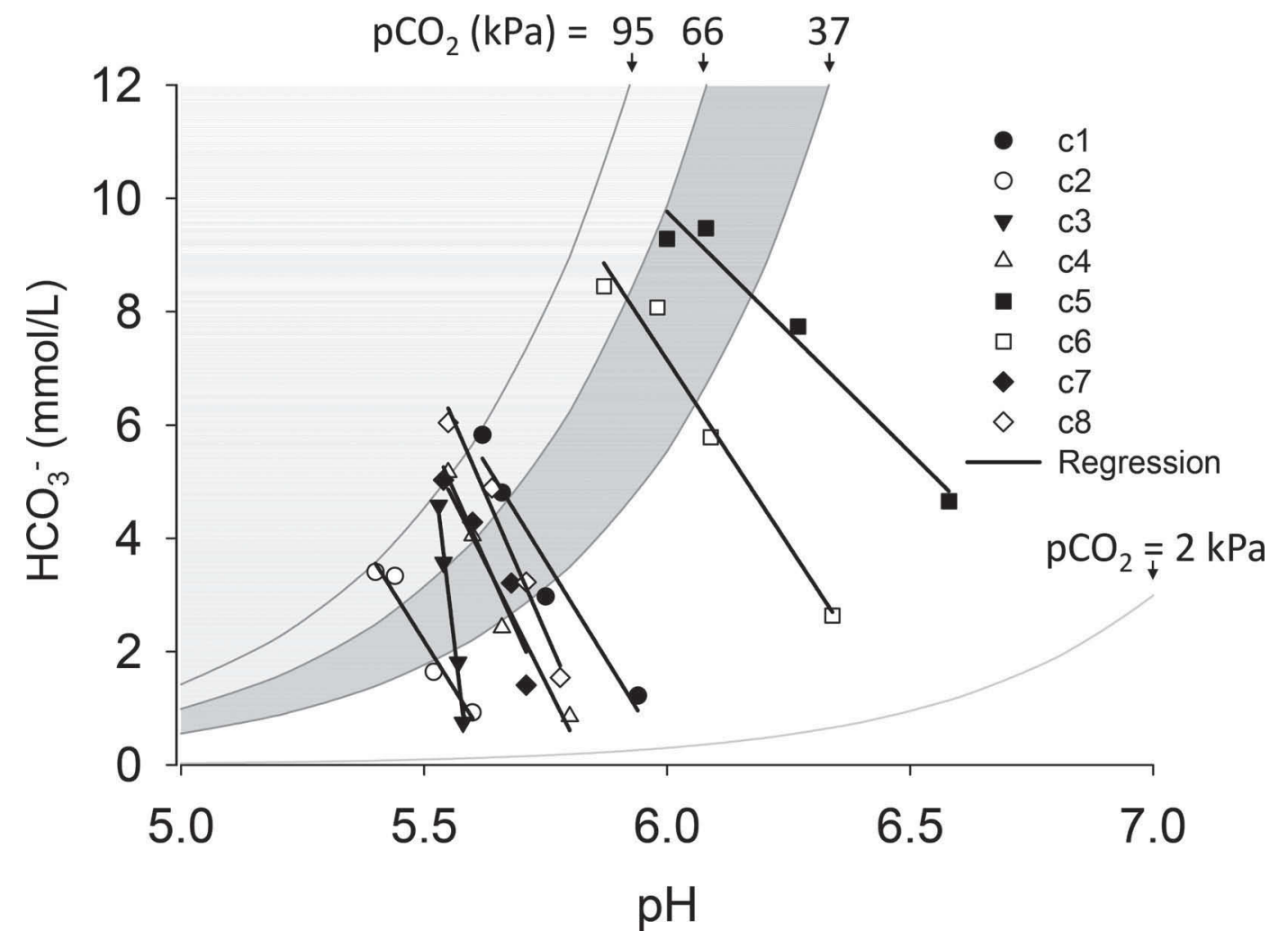

Figure 3. Davenport diagram showing the $\mathrm{HCO}_{3}{ }^{-}$concentration over the measured $\mathrm{pH}$ of ruminal samples taken from 8 concentrate/silagefed cows (designated c1 to c8). For explanation, see Figure 2 and text. $\mathrm{pCO}_{2}=$ partial pressure of $\mathrm{CO}_{2}$. 
a

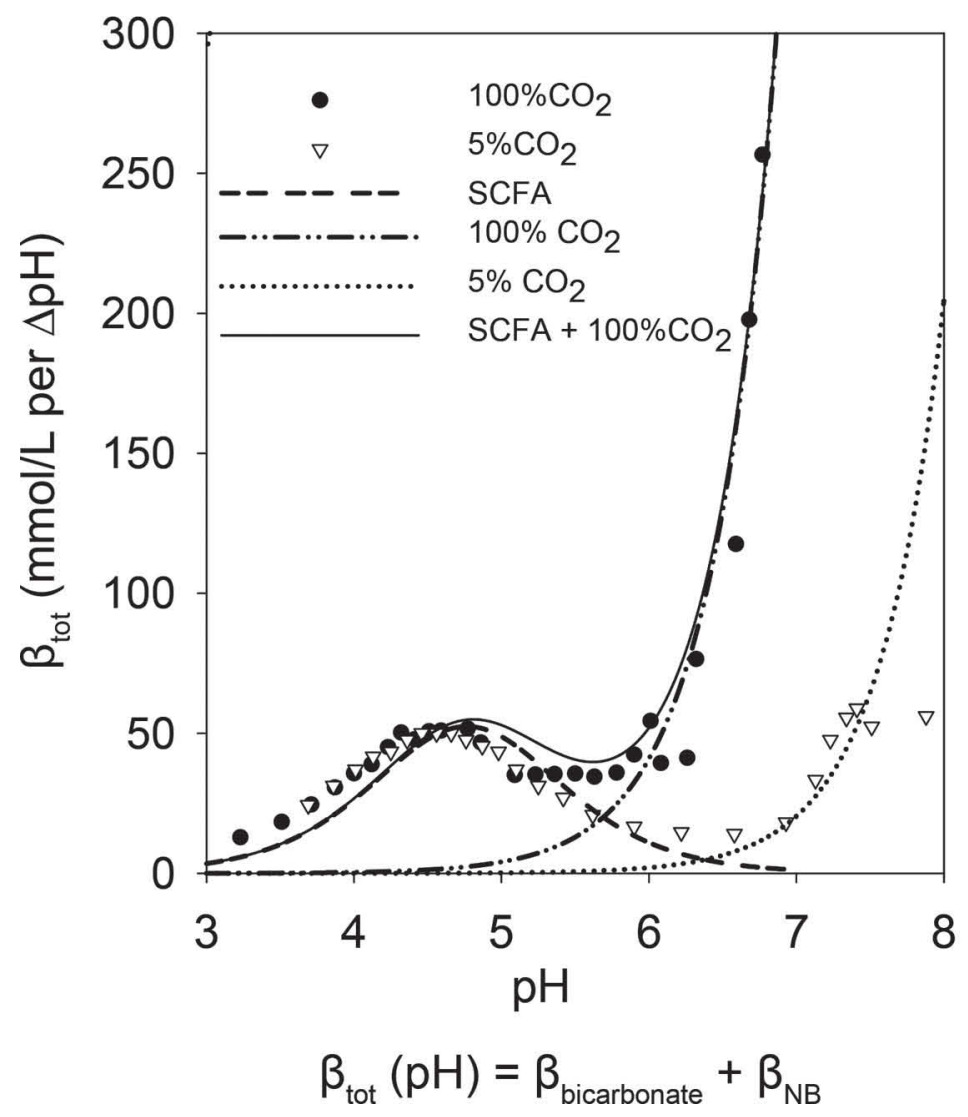

b

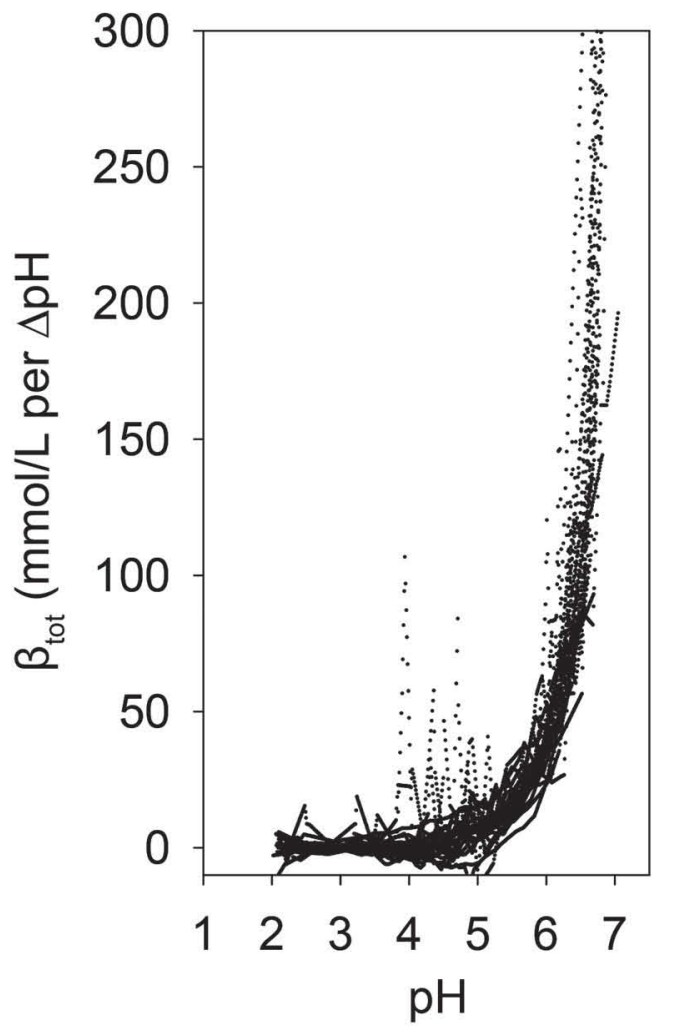

$\Delta \beta_{\text {tot }}(\mathrm{pH})=2.302 \cdot \alpha \cdot \Delta \mathrm{pCO}_{2} \cdot 10^{(\text {(ph-pKapp) }}$

Figure 4. (a) Buffer capacity obtained from one ruminal sample (h1, d 15, $0700 \mathrm{~h}$ ) after titration at 2 values of partial pressure of $\mathrm{CO}_{2}$ [partial pressure of $\mathrm{CO}_{2}\left(\mathrm{pCO}_{2}\right) ; 5 \% \mathrm{CO}_{2} \approx 4.75 \mathrm{kPa}$ and $100 \% \mathrm{CO}_{2} \approx 94.98 \mathrm{kPa} ; \Delta \mathrm{pCO}_{2}=90.23 \mathrm{kPa} ; 38^{\circ} \mathrm{C}$. The dashed line was calculated using the concentrations of individual short-chain fatty acids (SCFA) as measured by gas chromatography according to $\beta_{\mathrm{NB}}=2.302 \cdot[$ acetate] $/$ $\left(2+10^{(\mathrm{pH}-4.76)}+10^{(4.76-\mathrm{pH})}\right)+2.302 \cdot[$ propionate $] /\left(2+10^{(\mathrm{pH}-4.88)}+10^{(4.88-\mathrm{pH})}\right)+2.302 \cdot[$ butyrate $] /\left(2+10^{(\mathrm{pH}-4.82)}+10^{(4.82-\mathrm{pH})}\right)$. The dash-dotted and dotted lines reflect the contribution of bicarbonate to total buffer capacity and were calculated from $\beta_{\text {bicarbonate }}=2.302 \cdot \alpha \cdot \mathrm{pCO}_{2} \cdot 10^{(\mathrm{pH}-\mathrm{d}-\mathrm{pKapp})}$ for values of $\mathrm{pCO}_{2}$ of 100 and $5 \%$, respectively, and $\mathrm{pK}=6.1$ and $\alpha=0.226 \mathrm{mmol} \cdot \mathrm{L}^{-1} \cdot \mathrm{kPa}^{-1}$. The solid line represents the sum $\beta_{\text {tot }}(\mathrm{pH})=\beta_{\text {bicarbonate }}$ $+\beta_{\mathrm{NB}}$ of both curves and reflects the contribution of SCFA and bicarbonate to total buffer capacity. The data could also be fitted without prior knowledge of SCFA concentration, yielding a slightly better fit and an orientation for the total SCFA in the sample ([SCFA $]_{\text {fit }}$ ) (see text for details). (b) The figure shows the difference $\Delta \beta_{\text {tot }}(\mathrm{pH})$ between the buffer capacity at 4.75 and $94.98 \mathrm{kPa}^{\mathrm{CO}_{2}}$ at each value of pH after interpolation of the individual curves of all hay/silage-fed animals. The buffer capacity of the nonbicarbonate buffers is cancelled out of the equation, and accordingly, data could be fitted via $\Delta \beta_{\text {tot }}=\beta_{\text {bicarbonate }}=2.302 \cdot \alpha \cdot \Delta \mathrm{pCO}_{2} \cdot 10$ (pH-d-pKapp) . For the hay/silage-fed animals, the approach yielded $\alpha=0.223 \pm 0.003 \mathrm{mmol} \cdot \mathrm{L}^{-1} \cdot \mathrm{kPa}^{-1}, \mathrm{pK}_{\text {app }}=6.049 \pm 0.009$, and a mean calibration error of the $\mathrm{pH}$ electrode $\mathrm{d}=0.041 \pm 0.007 \mathrm{pH}$ units.

Regression analysis of the fitting results over the measured SCFA values yielded $[\mathrm{SCFA}]_{\mathrm{fit}}=-5.7 \mathrm{mmol} \cdot \mathrm{L}^{-1}$ $+1.07 \cdot[\mathrm{SCFA}]_{\text {measured }}\left(\mathrm{R}^{2}=0.60\right)$. In the concentrate/ silage-fed animals, [SCFA $]_{\text {measured }}$ was $89 \pm 4 \mathrm{mmol} \cdot \mathrm{L}^{-1}$, which was significantly lower than that determined via titration of $[\mathrm{SCFA}]_{\mathrm{fit}}=125 \pm 7 \mathrm{mmol} \cdot \mathrm{L}^{-1}(P<0.001)$. In its present form, the titration method clearly cannot be considered a suitable alternative for the estimation of the SCFA concentration in ruminal fluid.

\section{Base Excess}

The amount of acid necessary to adjust the samples to a $\mathrm{pH}$ of 6.4 or 5.8 was determined for samples equilibrated with $100 \% \mathrm{CO}_{2}(94.98 \mathrm{kPa})$ by interpolation from the titration curves. In the hay/silage-fed animals, a mean of $0.5 \pm 3 \mathrm{mmol} \cdot \mathrm{L}^{-1}\left(\mathrm{BE}_{(6.4)}\right)$ or 39.2 $\pm 2.8\left(\mathrm{BE}_{(5.8)}\right)$ of $\mathrm{HCl}$ had to be added, reflecting the amount of acid necessary to adjust sample $\mathrm{pH}$ to 6.4 or 5.8, respectively. Both values were in close agreement with those obtained from equations derived from Henderson-Hasselbalch theory (see Appendix), again suggesting that SCFA is the primary nonbicarbonate buffer present in this group of animals. Accordingly, the correlation between $\mathrm{BE}$ and ruminal $\mathrm{pH}$ was acceptable $\left(\mathrm{BE}_{(6.4)}: \mathrm{R}^{2}=0.72, \mathrm{BE}_{(5.8)}: \mathrm{R}^{2}=0.63\right)$, as was the correlation between $\mathrm{BE}$ and SCFA concentration (Pearson product moment $P<0.01$ for both $\mathrm{BE}_{(6.4)}$ and $\left.\mathrm{BE}_{(5.8)}\right)$. 
In the concentrate/silage-fed animals, the starting $\mathrm{pH}$ was below 6.4 and $\mathrm{NaOH}$ had to be added, resulting in a mean $\mathrm{BE}_{(6.4)}$ of $-93 \pm 18.5 \mathrm{mmol} \cdot \mathrm{L}^{-1}$ and $\mathrm{BE}_{(5.8)}$ of $-22.2 \pm 13.8 \mathrm{mmol} \cdot \mathrm{L}^{-1}$ for samples gassed with $100 \%$ $\mathrm{CO}_{2}(P<0.0001$ versus hay/silage $)$. The $\mathrm{BE}$ showed no correlation to $\mathrm{pH}$ as measured directly in the rumen $\left(\mathrm{BE}_{(6.4)}: \mathrm{R}^{2}=0.004, \mathrm{BE}_{(5.8)}: \mathrm{R}^{2}=0.002\right)$ or in the reticulorumen by a $\mathrm{pH}$-sensitive probe $\left(\mathrm{BE}_{(6.4)}: \mathrm{R}^{2}=0.06\right.$, $\left.\mathrm{BE}_{(5.8)}: \mathrm{R}^{2}=0.013\right)$. In this group of animals, $\mathrm{BE}_{(5.8)}$ was found to scatter strongly, with values measured that ranged from -50 to $-120 \mathrm{mmol} \cdot \mathrm{L}^{-1}$, although corresponding $\mathrm{pH}$ values were roughly the same (between 5.5 and 5.7). In the animals with a highly negative base excess, buffering anions were apparently highly protonated so that much base was necessary before the $\mathrm{pH}$ could be shifted to the desired range. Note that in the corresponding animals, these protonated buffers have to be absorbed from the rumen with potential negative effect on intraepithelial $\mathrm{pH}$ homeostasis.

In contrast to what was observed in the hay/silage fed animals, no correlation could be found between the total or individual SCFA concentrations as measured by gas chromatography and the BE in the concentrate/ silage-fed animals. This is not surprising because gas chromatography does not distinguish between the protonated and the unprotonated form of SCFA. In the $\mathrm{pH}$ range in the concentrate/silage group (5.7 to 5.3), the percentage of protonated SCFA can be expected to vary from 11 to $24 \%$. In addition, other buffers may have contributed to total buffering power in this group of animals (see Appendix). Notably, the protons bound by these buffers were released upon titration to higher values of $\mathrm{pH}$ and can be expected to burden the acidbase balance of cells within the ruminal epithelium during the absorption process. In practical terms, measuring base excess may be the simplest way to assess the contribution of multiple buffers to the acid load of the epithelium and estimate the total quantity of protons bound.

\section{DISCUSSION}

Understanding ruminal buffering is not possible if no reliable values for the buffer constants of the bicarbonate system are available. In this study, 2 independent methods were used to measure the solubility of $\mathrm{CO}_{2}$ (Henry's constant $\alpha$ ) and for the $\mathrm{pK}_{\text {app }}$ of $\mathrm{H}_{2} \mathrm{CO}_{3}$ in ruminal fluid at $38^{\circ} \mathrm{C}$. The values found $[\alpha=0.234 \pm$ $0.005 \mathrm{mmol} \cdot \mathrm{L}^{-1} \cdot \mathrm{kPa}^{-1}, \mathrm{pK}_{\text {app }}=6.11 \pm 0.02 ;(\mathrm{n} / \mathrm{n}=$ $31 / 10)$ ] were essentially identical to those established for either blood plasma or isotonic salt solution at $37^{\circ} \mathrm{C}$ (Andersen, 1962; Segel, 1976). Although this result is hardly surprising and has been previously postulated
(Kohn and Dunlap, 1998), we are not aware of any study where this has been stringently shown.

Our study further clearly shows that spurious changes in $\mathrm{pCO}_{2}$ can significantly compromise measurements of ruminal $\mathrm{pH}$. We demonstrate that a more rigorous approach with equilibration of ruminal samples to a standard $\mathrm{pCO}_{2}$ and subsequent determination of base excess is technically feasible and may prove useful in the diagnosis of disturbances of ruminal acid-base homeostasis. Furthermore, we introduce a new simple method for the determination of $\alpha$ and $\mathrm{pK}$ of the bicarbonate system that has not, to our knowledge, been described before. This method should be generally helpful for estimating $\alpha$ and pK in physiological multi-buffer solutions. Finally, in the Appendix, we provide equations suitable for estimating the response of a mixed SCFA/ $\mathrm{HCO}_{3}{ }^{-}$buffer solution to changes in various parameters such as $\mathrm{pCO}_{2}$ and $\mathrm{HCO}_{3}^{-}$.

\section{Conversion of $\mathrm{HCO}_{3}{ }^{-}$to $\mathrm{CO}_{2}$ in Ruminal Fluid}

Although the principles underlying the conclusions of this study are hardly new, considerable debate has occurred concerning the extent to which salivary $\mathrm{HCO}_{3}{ }^{-}$is converted to $\mathrm{CO}_{2}$ in the rumen, with implications both for understanding ruminal buffering and the driving forces relevant for transport physiology. Our direct measurements of the $\left[\mathrm{HCO}_{3}{ }^{-}\right]$concentration in ruminal fluid at different values of $\mathrm{pH}$ and $\mathrm{pCO}_{2}$ clearly show that the standard constants for bicarbonate buffering apply and that the classical isohydric principle fully holds for ruminal fluid (Nguyen et al., 2009). This principle states that the overall $\mathrm{pH}$ determines the relationship between the concentrations of each individual acid and base pair in a multi-buffer system. The $\mathrm{HCO}_{3}{ }^{-}$ concentration of a sample is thus determined by $\mathrm{pH}$ and the $\mathrm{pCO}_{2}$ as given by the classical Henderson-Hasselbalch equation.

In this context, it is important to realize that because $\mathrm{pCO}_{2}$ is maintained at near constant levels due to eructation and absorption of $\mathrm{CO}_{2}$, the rumen has to be considered an open buffer system. This concept is well known from systemic acid-base physiology, where the bicarbonate system buffers plasma to $\mathrm{pH}$ 7.4, far from the $\mathrm{pK}$ of 6.1 . The $\mathrm{pH}$ falls with rising values of $\mathrm{pCO}_{2}$ and accordingly, hyperventilation with removal of $\mathrm{CO}_{2}$ from the body via the lungs can correct metabolic acidosis, whereas clinically, infusions of $\mathrm{NaHCO}_{3}$ shift $\mathrm{pH}$ back to the neutral range. Likewise, in the rumen, additional $\mathrm{HCO}_{3}^{-}$(e.g., via influx of saliva or transport across the ruminal wall) buffers the system to values that are much more alkalic than the $\mathrm{pK}$ of the bicarbonate system (Kohn and Dunlap, 1998). Cor- 
responding shifts in the ratio of acetate to acetic acid will follow according to

$$
\begin{aligned}
& \mathrm{pH}=\mathrm{pK}_{\mathrm{H}_{2} \mathrm{CO}_{3}}+\log _{10}\left(\frac{\left[\mathrm{HCO}_{3}^{-}\right]}{\alpha \cdot \mathrm{pCO}_{2}}\right) \\
& =\mathrm{pK}_{\text {acetic acid }}+\log _{10}\left(\frac{\left[\text { acetate }^{-}\right]}{[\text {acetic acid }]^{-}}\right) \text {. }
\end{aligned}
$$

\section{Consequences for Transport Physiology}

Using equation [10] and the constants determined in this study, it is possible to calculate the concentration of $\left[\mathrm{HCO}_{3}{ }^{-}\right]$in the rumen (or any other organ of the fermentative gut) for any given value of $\mathrm{pH}$ and $\mathrm{pCO}_{2}$, thus allowing an estimate of the driving forces for transport processes.

In the rumen, a large albeit variable fraction of the protons produced in the fermentational process are neutralized by salivary $\mathrm{NaHCO}_{3}$, forming $\mathrm{H}_{2} \mathrm{O}$ and $\mathrm{CO}_{2}$, whereas SCFA anions are absorbed with $\mathrm{Na}^{+}$(or $\mathrm{K}^{+}$released from forage) in a process that minimizes the acid load of the epithelium (Aschenbach et al., 2011). At a total concentration of $100 \mathrm{mmol} \cdot \mathrm{L}^{-1} \mathrm{SCFA}$ and $\mathrm{pH} \mathrm{6.1,} \mathrm{the} \mathrm{concentration} \mathrm{of} \mathrm{the} \mathrm{protonated} \mathrm{form}$ (H-SCFA) is less than $\sim 5 \mathrm{mmol} \cdot \mathrm{L}^{-1}$, so that the rest of the SCFA anions (or $\sim 95 \mathrm{mmol} \cdot \mathrm{L}^{-1}$ ) are coupled to strong cations such as $\mathrm{Na}^{+}$and $\mathrm{K}^{+}$, reflecting the concentrations found via direct measurement (Majak and Hall, 1989).

Due to the shortage of protons, net transport of SCFA across the rumen and other fermentative organs can thus hardly proceed via lipid diffusion alone. Current models of SCFA transport involve an apical anion exchanger with secretion of buffering $\mathrm{HCO}_{3}{ }^{-}$(Hume et al., 1993; Kramer et al., 1996; Aschenbach et al., 2009; Dengler et al., 2014). At a pH of 6.1 and a $\mathrm{pCO}_{2}$ of $60 \mathrm{kPa},\left[\mathrm{HCO}_{3}{ }^{-}\right]$will drop to values under 15 mmol. $\mathrm{L}^{-1}$ (see Figures 2 and 3 ), contributing to the driving force for the uptake of SCFA anions via $\mathrm{SCFA}^{-}$/ $\mathrm{HCO}_{3}{ }^{-}$exchange. At high ruminal $\mathrm{pH}$, a high intracellular $\left[\mathrm{HCO}_{3}{ }^{-}\right]_{\mathrm{i}}$ (maintained by apical influx of $\mathrm{CO}_{2}$, basolateral influx of $\mathrm{HCO}_{3}{ }^{-}$, efflux of protons to either side, or a combination of these) and a rapid basolateral extrusion of SCFA can maintain the driving force necessary for the uptake of individual SCFA in exchange for $\mathrm{HCO}_{3}^{-}$.

Numerous studies demonstrate the involvement of apical sodium-proton exchange (NHE3) in restoring cytosolic $\mathrm{pH}$, which is challenged both by influx of protons and by loss of $\mathrm{HCO}_{3}^{-}$(Gäbel et al., 1991; Rabbani et al., 2011). This mechanism supplies protons to the apical side, protonating SCFA for influx via diffusive mechanisms and maintaining the apical $\mathrm{HCO}_{3}{ }^{-}$gradient for anion exchange. In an epithelium in which intracellular $\mathrm{pH}$ is maintained by an apical NHE (Rabbani et al., 2011), a net uptake of SCFA ${ }^{-}$ with $\mathrm{Na}^{+}$will follow. Basolateral efflux of SCFA anions could proceed through a large anion channel (Stumpff et al., 2009; Georgi et al., 2014), driven by the gradient generated by basolateral potassium channels and the $\mathrm{Na}^{+} / \mathrm{K}^{+}$-ATPase.

In situations where salivary secretion is insufficient, an increasing amount of protons will have to be transported across the epithelium and eliminated basolaterally, involving various transport proteins such as basolateral NHE1 (Rabbani et al., 2011), $\mathrm{NaHCO}_{3}{ }^{-}$cotransport (Huhn et al., 2003), and an anion exchanger that extrudes $\mathrm{SCFA}^{-}$anions in exchange for $\mathrm{HCO}_{3}{ }^{-}$ (Dengler et al., 2014).

\section{Base Excess}

In the evaluation of systemic acid-base balance, clinicians have long determined 3 parameters: $\mathrm{pH}$, actual $\mathrm{pCO}_{2}$, and $\mathrm{BE}$, which is equivalent to the amount of acid required to return the $\mathrm{pH}$ of a blood sample to a normal value (7.4) under standard conditions $\left(37^{\circ} \mathrm{C}\right.$, $\mathrm{pCO}_{2}=5.33 \mathrm{kPa}$; Jorgensen and Astrup, 1957). For ruminal samples, standard $\mathrm{pCO}_{2}$ might be set to $\sim 60$ $\mathrm{kPa}$, although from our current perspective, utilization of $100 \% \mathrm{CO}_{2}$, which is available at low cost in most laboratories, may represent an alternative more feasible in practical and economic terms as a standard. In this study, $\mathrm{pH}$ values both above (6.4) and on the threshold to subacute ruminal acidosis (5.8) were chosen as standards for determination of $\mathrm{BE}$, although a higher $\mathrm{pH}$ value reflecting cytosolic $\mathrm{pH}$ might be an alternative worth considering.

Determination of the BE of a sample makes it possible to distinguish between unprotonated and protonated buffers. A negative BE thus reflects the amount of protons that will have to be absorbed across the ruminal wall and buffered by cellular mechanisms to prevent epithelial damage. Theoretically at least, the BE should be useful as a diagnostic tool particularly at low $\mathrm{pH}$ when the buffering capacity of SCFA rises. In this situation, large changes in the production of acid will have little effect on ruminal $\mathrm{pH}$, but a major effect on the total amount of protons that enter the cytosol and challenge epithelial homeostasis (Enemark, 2008; Stumpff et al., 2009). Ultimately, clinical trials will have to show whether determination of the BE will yield greater diagnostic accuracy in determining what animals are likely to develop clinical symptoms than classical approaches. 


\section{Consequences for the Evaluation of Ruminal Acid-Base Balance}

Consequences for many clinical situations abound. Attempts to reduce the levels of methane in the rumen by defaunation might result in higher levels of $\mathrm{pCO}_{2}$, and thus reduce ruminal pH. Simultaneously, ruminal buffer capacity will increase (equation [9]). The clinical implications of this are hard to predict theoretically, but investigations are clearly necessary.

Most importantly, any spurious drop in the $\mathrm{pCO}_{2}$ of samples of ruminal fluid, as observed when collecting samples from the rumen via an aspirating sampling device in this study and others (Enemark, 2008), can be expected to significantly affect the $\mathrm{pH}$ that is subsequently measured. Such variation in the $\mathrm{pCO}_{2}$ may well underlie a significant part of the variability seen in studies attempting to correlate ruminal $\mathrm{pH}$ with clinical symptoms of ruminal acidosis.

In conclusion, the effect of changes in $\mathrm{pCO}_{2}$, whether due to sampling technique or escape of $\mathrm{CO}_{2}$ through a fistula opening or other factors, have to be considered when studying ruminal acidosis. An attempt to introduce a generally accepted protocol with fixed levels of temperature, $\mathrm{pCO}_{2}$, and determination of $\mathrm{BE}$ for measuring the acid-base status of ruminal samples appears overdue.

\section{ACKNOWLEDGMENTS}

We thank Martin Grunau and Beate Pellner (Institute for Veterinary Physiology, Freie Universität Berlin) for their help and expertise in collecting and titrating samples. This study would not have been possible without the generous help of $\mathrm{K}$. Müller and the staff of the ruminant clinic at the Freie Universität Berlin and the staff of the Federal Research Institute for Animal Health in Braunschweig, Germany. Funding for K. Hille, J. Rosendahl, H. Braun, and M. Grunau was provided by the "Akademie für Tierschutz" and by the European Social Fund (ESF) and the German Federal Ministry of Economics and Energy based on a decision of the German Parliament.

\section{REFERENCES}

Allen, M. S. 1997. Relationship between fermentation acid production in the rumen and the requirement for physically effective fiber. J. Dairy Sci. 80:1447-1462.

Andersen, O. S. 1962. The first dissociation exponent of carbonic acid as a function of pH. Scand. J. Clin. Lab. Invest. 14:587-597.

Aschenbach, J. R., S. Bilk, G. Tadesse, F. Stumpff, and G. Gabel. 2009. Bicarbonate-dependent and bicarbonate-independent mechanisms contribute to nondiffusive uptake of acetate in the ruminal epithelium of sheep. Am. J. Physiol. Gastrointest. Liver Physiol. 296:G1098-G1107.
Aschenbach, J. R., G. B. Penner, F. Stumpff, and G. Gabel. 2011. Ruminant Nutrition Symposium: Role of fermentation acid absorption in the regulation of ruminal pH. J. Anim. Sci. 89:1092-1107.

Bramley, E., I. J. Lean, W. J. Fulkerson, M. A. Stevenson, A. R. Rabiee, and N. D. Costa. 2008. The definition of acidosis in dairy herds predominantly fed on pasture and concentrates. J. Dairy Sci. 91:308-321.

Cameron, J. N. 1971. Rapid method for determination of total carbon dioxide in small blood samples. J. Appl. Physiol. 31:632-634.

Counotte, G. H., A. T. van't Klooster, J. van der Kuilen, and R. A. Prins. 1979. An analysis of the buffer system in the rumen of dairy cattle. J. Anim. Sci. 49:1536-1544.

Davenport, H. W. 1974. The ABC of Acid-Base Chemistry: The Elements of Physiological Blood-Gas Chemistry for Medical Students and Physicians. 6th ed. The University of Chicago Press, Chicago, IL.

Dengler, F., R. Rackwitz, F. Benesch, H. Pfannkuche, and G. Gabel. 2014. Bicarbonate-dependent transport of acetate and butyrate across the basolateral membrane of sheep rumen epithelium. Acta Physiol. (Oxf.). 210:403-414.

Duffield, T., J. C. Plaizier, A. Fairfield, R. Bagg, G. Vessie, P. Dick, J. Wilson, J. Aramini, and B. McBride. 2004. Comparison of techniques for measurement of rumen $\mathrm{pH}$ in lactating dairy cows. J. Dairy Sci. 87:59-66.

Enemark, J. M. 2008. The monitoring, prevention and treatment of sub-acute ruminal acidosis (SARA): A review. Vet. J. 176:32-43.

Gäbel, G., S. Vogler, and H. Martens. 1991. Short-chain fatty acids and $\mathrm{CO}_{2}$ as regulators of $\mathrm{Na}+$ and $\mathrm{Cl}$ - absorption in isolated sheep rumen mucosa. J. Comp. Physiol. B 161:419-426.

Georgi, M. I., J. Rosendahl, F. Ernst, D. Gunzel, J. R. Aschenbach, H. Martens, and F. Stumpff. 2014. Epithelia of the ovine and bovine forestomach express basolateral maxi-anion channels permeable to the anions of short-chain fatty acids. Pflugers Arch. 466:1689-1712.

Heisler, N. 1986. Buffering and transmembrane ion transfer processes. Pages 3-48 in Acid-Base Regulation in Animals. N. Heisler, ed. Elsevier, Amsterdam, the Netherlands.

Huhn, K., F. Muller, K. U. Honscha, H. Pfannkuche, and G. Gäbel. 2003. Molecular and functional evidence for a $\mathrm{Na}(+)-\mathrm{HCO}^{3}(-)-$ cotransporter in sheep ruminal epithelium. J. Comp. Physiol. B 173:277-284.

Hume, I. D., W. H. Karasov, and B. W. Darken. 1993. Acetate, butyrate and proline uptake in the caecum and colon of prairie voles (Microtus ochrogaster). J. Exp. Biol. 176:285-297.

Jorgensen, K., and P. Astrup. 1957. Standard bicarbonate, its clinical significance, and a new method for its determination. Scand. J. Clin. Lab. Invest. 9:122-132.

Kleen, J. L., G. A. Hooijer, J. Rehage, and J. P. Noordhuizen. 2003 Subacute ruminal acidosis (SARA): A review. J. Vet. Med. A Physiol. Pathol. Clin. Med. 50:406-414.

Kohn, R. A., and T. F. Dunlap. 1998. Calculation of the buffering capacity of bicarbonate in the rumen and in vitro. J. Anim. Sci. 76:1702-1709.

Kölling, K. 1974. Ruminoreticulum motility. IV. Intraruminal pressure during the reticulum-rumen cycle and during eructation. Zentralbl. Veterinarmed. A 21:445-456.

Kramer, T., T. Michelberger, H. Gurtler, and G. Gäbel. 1996. Absorption of short-chain fatty acids across ruminal epithelium of sheep. J. Comp. Physiol. B 166:262-269.

Krause, K. M., and G. R. Oetzel. 2005. Inducing subacute ruminal acidosis in lactating dairy cows. J. Dairy Sci. 88:3633-3639.

Krause, K. M., and G. R. Oetzel. 2006. Understanding and preventing subacute ruminal acidosis in dairy herds: A review. Anim. Feed Sci. Technol. 126:215-236.

Li, S., E. Khafipour, D. O. Krause, A. Kroeker, J. C. RodriguezLecompte, G. N. Gozho, and J. C. Plaizier. 2012. Effects of subacute ruminal acidosis challenges on fermentation and endotoxins in the rumen and hindgut of dairy cows. J. Dairy Sci. 95:294-303.

Majak, W., and J. W. Hall. 1989. Sodium and potassium concentrations in ruminal contents after feeding bloat-inducing alfalfa to cattle. Can. J. Anim. Sci. 70:235-241. 
Maulfair, D. D., K. K. McIntyre, and A. J. Heinrichs. 2013. Subacute ruminal acidosis and total mixed ration preference in lactating dairy cows. J. Dairy Sci. 96:6610-6620.

McArthur, J. M., and J. E. Miltimore. 1961. Rumen gas analysis by gas-solid chromatography. Can. J. Anim. Sci. 41:187-196.

Mertens, D. R. 1997. Creating a system for meeting the fiber requirements of dairy cows. J. Dairy Sci. 80:1463-1481.

Mortimer, R. G. 2008. Chapter 7, Chemical Equilibrium. in Physical Chemistry. 3rd ed. Elsevier Academic Press, Birmingham, MA

Nguyen, M. K., L. Kao, and I. Kurtz. 2009. Calculation of the equilibrium $\mathrm{pH}$ in a multiple-buffered aqueous solution based on partitioning of proton buffering: A new predictive formula. Am. J. Physiol. Renal Physiol. 296:F1521-F1529.

Pieper, R., S. Kroger, J. F. Richter, J. Wang, L. Martin, J. Bindelle, J. K. Htoo, D. von Smolinski, W. Vahjen, J. Zentek, and A. G. Van Kessel. 2012. Fermentable fiber ameliorates fermentable protein-induced changes in microbial ecology, but not the mucosal response, in the colon of piglets. J. Nutr. 142:661-667.

Plaizier, J. C., E. Khafipour, S. Li, G. N. Gozho, and D. O. Krause. 2012. Subacute ruminal acidosis (SARA), endotoxins and health consequences. Anim. Feed Sci. Technol. 172:9-21.

Plaizier, J. C., D. O. Krause, G. N. Gozho, and B. W. McBride. 2008. Subacute ruminal acidosis in dairy cows: The physiological causes, incidence and consequences. Vet. J. 176:21-31.

Rabbani, I., C. Siegling-Vlitakis, B. Noci, and H. Martens. 2011. Evidence for NHE3-mediated Na transport in sheep and bovine forestomach. Am. J. Physiol. Regul. Integr. Comp. Physiol. 301:R313R319

Segel, I. H. 1976. Biochemical Calculations. 2nd ed. John Wiley \& Sons, New York, NY.

Stumpff, F., H. Martens, S. Bilk, J. R. Aschenbach, and G. Gabel. 2009. Cultured ruminal epithelial cells express a large-conductance channel permeable to chloride, bicarbonate, and acetate. Pflugers Arch. 457:1003-1022.

Terblanche, J. S., E. Marais, S. K. Hetz, and S. L. Chown. 2008. Control of discontinuous gas exchange in Samia cynthia: effects of atmospheric oxygen, carbon dioxide and moisture. J. Exp. Biol. 211:3272-3280.

Turner, A. W., and V. E. Hodgetts. 1955. Buffer systems in the rumen of sheep. I. $\mathrm{pH}$ and bicarbonate concentration in relationship to $\mathrm{pCO}_{2}$. Crop Pasture Sci. 6:125-144.

Van Slyke, D. E., and G. E. Cullen. 1917. On the measurement of buffer values and on the relationship of buffer value to the dissociation constant of the buffer and the concentration and reaction of the buffer solution. J. Biol. Chem. 30:289-346.

Yang, W. Z., and K. A. Beauchemin. 2006. Effects of physically effective fiber on chewing activity and ruminal $\mathrm{pH}$ of dairy cows fed diets based on barley silage. J. Dairy Sci. 89:217-228.

Zebeli, Q., J. R. Aschenbach, M. Tafaj, J. Boguhn, B. N. Ametaj, and W. Drochner. 2012. Invited review: Role of physically effective fiber and estimation of dietary fiber adequacy in high-producing dairy cattle. J. Dairy Sci. 95:1041-1056.

\section{APPENDIX}

\section{Buffer Calculations for Solutions Containing SCFA and Bicarbonate}

To understand ruminal buffering, intuition will frequently not be enough and it is useful to have a mathematical model that simulates how an ideal buffer solution containing carbon dioxide, bicarbonate, and SCFA will respond if one of the parameters is changed. For instance, the practitioner will wish to estimate by how much the $\mathrm{pH}$ of ruminal fluid can be expected to change if the $\mathrm{pCO}_{2}$ changes (e.g., after aspiration of a sample using negative pressure), or in what way addi- tions of $\mathrm{NaHCO}_{3}$ (e.g., via saliva) will affect ruminal $\mathrm{pH}$. Furthermore, it may be important to estimate the total amount of protons in bound and unbound form in the solution that have to be buffered or transported across the ruminal epithelium. Such calculations are possible but not entirely trivial. For the interested reader, the relevant equations will therefore be derived in this Appendix. A convenient spreadsheet for such calculations can be obtained from the authors upon request.

It will be shown in what follows that 3 independent parameters reflecting the amount of protons, the bicarbonate buffer, and the nonbicarbonate buffer are required to define the system and calculate the changes that occur following an intervention.

\section{Calculating $\left[\mathrm{H}^{+}\right]_{\text {init, }}\left[\mathrm{CO}_{2}\right]_{\text {tot }}^{\text {init }}$ and $\left[\text { strong cation }{ }^{+}\right]_{\text {tot }}$ from the Initial Parameters}

We shall consider a buffer solution (e.g., ruminal fluid) with the following initial parameters:

total concentration of SCFA:

$$
\begin{gathered}
{[\mathrm{SCFA}]_{\mathrm{tot}}^{\mathrm{init}}=[\mathrm{HSCFA}]_{\mathrm{init}}+\left[\mathrm{SCFA}^{-}\right]_{\text {init }}=100 \mathrm{mmol} \cdot \mathrm{L}^{-1},} \\
\text { initial pH: } \mathrm{pH}_{\text {init }}=6.4
\end{gathered}
$$

initial partial pressure of $\mathrm{CO}_{2}$ :

$$
\mathrm{pCO}_{2}^{\text {init }}=70 \mathrm{kPa},
$$

where [SCFA] tot designates the sum of the undissociated form ([HSCFA $]$ ) and the dissociated, anionic form ([SCFA $\left.\left.{ }^{-}\right]\right)$. The relevant constants will be set as follows: $\alpha=0.234 \mathrm{mmol} \cdot \mathrm{L}^{-1} \cdot \mathrm{kPa}^{-1}$ (Henry's constant as determined in this study), $\mathrm{pK}_{\mathrm{CO}_{2}}=6.11$ (dissociation constant of bicarbonate), and $\mathrm{pK}_{\mathrm{SCFA}} \approx 4.8$ (mean dissociation constant of the SCFA).

The initial concentrations of $\left[\mathrm{H}_{2} \mathrm{CO}_{3}\right],\left[\mathrm{HCO}_{3}{ }^{-}\right]$, and the total concentration of carbon dioxide, $\left[\mathrm{CO}_{2}\right]_{\text {tot }}$, are given by Henry's law and the Henderson-Hasselbalch equation:

$$
\begin{aligned}
& {\left[\mathrm{H}_{2} \mathrm{CO}_{3}\right]_{\text {init }}=\alpha \cdot \mathrm{pCO}_{2}^{\text {init }}=16.38 \mathrm{mmol} \cdot \mathrm{L}^{-1},}
\end{aligned}
$$

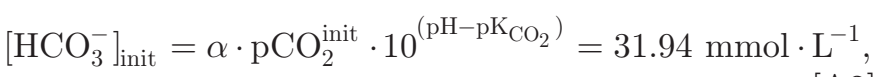

$$
\begin{aligned}
& {\left[\mathrm{CO}_{2}\right]_{\text {tot }}^{\text {init }}=\alpha \cdot \mathrm{pCO}_{2}^{\text {init }} \cdot\left(1+10^{\left(\mathrm{pH}_{\text {init }}-\mathrm{pK}_{\mathrm{CO}_{2}}\right)}\right)} \\
& =48.32 \mathrm{mmol} \cdot \mathrm{L}^{-1} \text {, }
\end{aligned}
$$


Likewise, the initial concentrations of undissociated and dissociated SCFA can be calculated from

$$
\begin{aligned}
& \mathrm{pH}_{\mathrm{init}}=\mathrm{pK}_{\mathrm{SCFA}}+\log _{10}\left(\frac{[\mathrm{SCFA}]_{\text {init }}}{[\mathrm{HSCFA}]_{\text {init }}}\right)= \\
& \mathrm{pK}_{\mathrm{SCFA}}+\log _{10}\left(\frac{[\mathrm{SCFA}]_{\mathrm{tot}}-[\mathrm{HSCFA}]_{\text {init }}}{[\mathrm{HSCFA}]_{\text {init }}}\right) \Leftrightarrow \\
& {[\mathrm{HSCFA}]_{\text {init }}=\frac{[\mathrm{SCFA}]_{\mathrm{tot}}}{\left(1+10^{\left(\mathrm{pH}-\mathrm{pK}_{\mathrm{SCFA}}\right)}\right.}=2.45 \mathrm{mmol} \cdot \mathrm{L}^{-1},}
\end{aligned}
$$

$$
\begin{aligned}
& {\left[\mathrm{SCFA}^{-}\right]_{\text {init }}=[\mathrm{SCFA}]_{\mathrm{tot}}-[\mathrm{HSCFA}]_{\mathrm{init}}} \\
& =\frac{10^{\left(\mathrm{pH}-\mathrm{pK}_{\mathrm{SCFA}}\right)} \cdot[\mathrm{SCFA}]_{\mathrm{tot}}}{\left(1+10^{\left(\mathrm{pH}^{\mathrm{pK}} \mathrm{SCFA}\right)}\right.}=97.55 \mathrm{mmol} \cdot \mathrm{L}^{-1} .
\end{aligned}
$$

For $\mathrm{pH}>4$, the concentration of free $\left[\mathrm{H}^{+}\right]=10^{-\mathrm{pH}}$ is negligible, so that the total initial concentration of protons $\left[\mathrm{H}^{+}\right]_{\text {tot }}^{\text {init }}$ is given by

$$
\begin{aligned}
& {\left[\mathrm{H}^{+}\right]_{\text {tot }}^{\text {init }}=\left[\mathrm{H}_{2} \mathrm{CO}_{3}\right]_{\text {init }}+\mathrm{HSCFA}_{\text {init }}+10^{-\mathrm{pH}_{\text {init }}}} \\
& \quad \cong \alpha \cdot \mathrm{pCO}_{2}^{\text {init }}+\frac{[\mathrm{SCFA}]_{\text {tot }}}{\left(1+10^{\left(\mathrm{pH}-\mathrm{pK} \mathrm{SCFA}_{\mathrm{SCA}}\right)}\right.}=18.83 \mathrm{mmol} \cdot \mathrm{L}^{-1} .
\end{aligned}
$$

For reasons of electroneutrality, the total concentration of strong cations [that is, cations other than free $\mathrm{H}^{+}$ (e.g., $\mathrm{Na}^{+}, \mathrm{K}^{+}$)] is given by the sum of the free anions in the system:

$$
\begin{aligned}
& {\left[\text { strong cation }{ }^{+}\right]_{\mathrm{tot}}=\left[\mathrm{HCO}_{3}^{-}\right]+\left[\mathrm{SCFA}^{-}\right]} \\
& \quad=\left[\mathrm{CO}_{2}\right]_{\mathrm{tot}}+[\mathrm{SCFA}]_{\mathrm{tot}}-\left[\mathrm{H}^{+}\right]_{\mathrm{tot}}=129.5 \mathrm{mmol} \cdot \mathrm{L}^{-1}
\end{aligned}
$$

\section{Conserved Quantities of the Buffer System}

Before any calculations are possible, it is important to identify what quantities of the system are conserved when the $\mathrm{pH}$ or the $\mathrm{pCO}_{2}$ change or both change.

The first conserved quantity of the system is the total amount of strong cations as given by equation [A7]. For instance, addition of $20 \mathrm{mmol}$ of $\mathrm{NaHCO}_{3}$ to $1 \mathrm{~L}$ of the mixed buffer solution above will have a complex effect on the $\mathrm{pH}$ and on the concentration of $\left[\mathrm{HCO}_{3}{ }^{-}\right]$in the system, with both changing in response to changes in the $\mathrm{pCO}_{2}$. However, regardless of $\mathrm{pH}$ and $\mathrm{pCO}_{2}$, the total amount of strong cations in the solution from above can easily be calculated according to

$$
\begin{aligned}
& {\left[\text { strong cation }{ }^{+}\right]_{\text {tot }}^{\text {end }}} \\
& =[\text { strong cation }]_{\text {tot }}^{+}+\Delta\left[\text { strong cation }{ }^{+}\right]_{\text {add }} \\
& =129.5 \mathrm{mmol} \cdot \mathrm{L}^{-1}+20 \mathrm{mmol} \cdot \mathrm{L}^{-1}=149.5 \mathrm{mmol} \cdot \mathrm{L}^{-1} .
\end{aligned}
$$

In this equation, $\Delta\left[\text { strong cation }{ }^{+}\right]_{\text {add }}$ designates the amount of cations added during the intervention, whereas the initial and final concentrations are designated with the corresponding superscripts.

Furthermore, the total concentration of SCFA, SCF$\mathrm{A}_{\text {tot }}$, does not change with $\mathrm{pH}$ and $\mathrm{pCO}_{2}$, although shifts in the ratio of the protonated and unprotonated form away from the initial values $\mathrm{HSCFA}_{\text {init }}$ and $\mathrm{SCFA}_{\text {init }}^{-}$will, of course, occur.

$$
\begin{aligned}
{[\mathrm{SCFA}]_{\mathrm{tot}}^{\mathrm{init}} } & =[\mathrm{HSCFA}]_{\mathrm{init}}+\left[\mathrm{SCFA}^{-}\right]_{\mathrm{init}} \\
& =[\mathrm{SCFA}]_{\mathrm{tot}}^{\text {end }}=[\mathrm{SCFA}]_{\mathrm{tot}}=\text { constant. }
\end{aligned}
$$

Given that both the total concentration of strong cations and the total concentration of SCFA are conserved, equation [A7] yields a third conserved quantity of the system, namely the bicarbonate excess, $[\mathrm{BCE}]_{\text {tot }}$, of the system, defined as the difference between $\left[\mathrm{CO}_{2}\right]$ tot and $\left[\mathrm{H}^{+}\right]_{\text {tot }}$ :

$$
\begin{aligned}
& {[\mathrm{BCE}]_{\mathrm{tot}}=\left[\mathrm{CO}_{2}\right]_{\mathrm{tot}}-\left[\mathrm{H}^{+}\right]_{\mathrm{tot}}=\left[\text { strong cation }{ }^{+}\right]_{\mathrm{tot}}} \\
& -[\mathrm{SCFA}]_{\mathrm{tot}}=\mathrm{constant}=29.49 \mathrm{mmol} \cdot \mathrm{L}^{-1} .
\end{aligned}
$$

Using $\left[\mathrm{CO}_{2}\right]_{\text {tot }}=\left[\mathrm{H}_{2} \mathrm{CO}_{3}\right]+\left[\mathrm{HCO}_{3}{ }^{-}\right]$and $\left[\mathrm{H}^{+}\right]_{\mathrm{tot}}=$ [HSCFA $]+\left[\mathrm{H}_{2} \mathrm{CO}_{3}\right]$, it follows that the difference between $\left[\mathrm{HCO}_{3}{ }^{-}\right]$and $[\mathrm{HSCFA}]$ is also conserved:

$$
\begin{aligned}
& {[\mathrm{BCE}]_{\mathrm{tot}}=\left[\mathrm{H}_{2} \mathrm{CO}_{3}\right]_{\text {init }}+\left[\mathrm{HCO}_{3}^{-}\right]_{\text {init }}-\left([\mathrm{HSCFA}]_{\text {init }}\right.} \\
& \left.+\left[\mathrm{H}_{2} \mathrm{CO}_{3}\right]_{\text {init }}\right)=\left[\mathrm{HCO}_{3}^{-}\right]_{\text {init }}-[\mathrm{HSCFA}]_{\text {init }} \\
& =\left[\mathrm{HCO}_{3}^{-}\right]_{\text {end }}-[\mathrm{HSCFA}]_{\text {end }}=[\mathrm{BCE}]_{\mathrm{tot}} .
\end{aligned}
$$

Equation [A10] also follows directly from the fact that in a mixed buffer system, $\mathrm{H}^{+}$ions generated from hydration and dissociation of $\mathrm{CO}_{2}$ are buffered by nonbicarbonate buffers so that the increase in the protonated form of the nonbicarbonate buffer $(\Delta[\mathrm{HSCFA}])$ is equal to the change in bicarbonate $\left(\Delta\left[\mathrm{HCO}_{3}{ }^{-}\right]\right)$(Heisler, 1986).

A final conserved quantity can be obtained using the isohydric principle, according to which the $\mathrm{pH}$ of a mix of buffers can be calculated from each buffer pair at any time point using the Henderson-Hasselbalch equation: 


$$
\begin{aligned}
\mathrm{pH} & =\mathrm{pK}_{\mathrm{SCFA}}+\log _{10}\left(\left[\mathrm{SCFA}^{-}\right] /[\mathrm{HSCFA}]\right) \\
& =\mathrm{pK}_{\mathrm{CO}_{2}}+\log _{10}\left(\left[\mathrm{HCO}_{3}^{-}\right] /\left[\mathrm{H}_{2} \mathrm{CO}_{3}\right]\right) .
\end{aligned}
$$

Using

$$
C=\log _{10}(\mathrm{a})-\log _{10}(\mathrm{~b})=\log _{10}(\mathrm{a} / \mathrm{b}) \Leftrightarrow 10^{C}=\mathrm{a} / \mathrm{b},
$$

we get

$$
\frac{\left[\mathrm{HCO}_{3}^{-}\right]}{\left[\mathrm{H}_{2} \mathrm{CO}_{3}\right]} \cdot \frac{[\mathrm{HSCFA}]}{\left[\mathrm{SCFA}^{-}\right]}=10^{\left(\mathrm{pK}_{\mathrm{SCFA}}-\mathrm{pK}_{\mathrm{CO}_{2}}\right)}=\text { constant }=0.049 .
$$

\section{Equations for the Open Buffer System}

We now wish to know how the open system changes with a variation of the initial parameters (e.g., when the $\mathrm{pCO}_{2}$ drops). This might be the case if a ruminal sample were aspired using a syringe, or if the partial pressure of methane in the rumen rises, displacing $\mathrm{CO}_{2}$.

Let $\left[\mathrm{HCO}_{3}^{-}\right]_{\text {end }}$ and $[\mathrm{HSCFA}]_{\text {end }}$ be the concentrations of bicarbonate and of protonated SCFA after the drop in $\mathrm{pCO}_{2}$.

Using

$$
\begin{gathered}
{\left[\mathrm{H}_{2} \mathrm{CO}_{3}\right]_{\text {end }}=\alpha \cdot \mathrm{pCO}_{2},} \\
(\text { Henry's law }) \\
{\left[\mathrm{HCO}_{3}^{-}\right]_{\text {end }}=[\mathrm{BCE}]_{\mathrm{tot}}+[\mathrm{HSCFA}]_{\text {end }},}
\end{gathered}
$$$$
\text { (from equation }[\mathrm{A} 10] \text { ) }
$$$$
\left[\mathrm{SCFA}^{-}\right]_{\mathrm{end}}=[\mathrm{SCFA}]_{\mathrm{tot}}-[\mathrm{HSCFA}]_{\mathrm{end}} \text {, }
$$$$
\text { (from equation }[\mathrm{A} 8] \text { ) }
$$

and using [A11], we get

$$
\begin{aligned}
& 10^{\left(\mathrm{pK}_{\mathrm{SCFA}}-\mathrm{pK}_{\mathrm{CO}_{2}}\right)}=\frac{\left[\mathrm{HCO}_{3}^{-}\right]_{\text {end }}}{\left[\mathrm{H}_{2} \mathrm{CO}_{3}\right]_{\text {end }}} \cdot \frac{[\mathrm{HSCFA}]_{\text {end }}}{\left[\mathrm{SCFA}^{-}\right]_{\text {end }}} \\
& =\frac{\left([\mathrm{BCE}]_{\mathrm{tot}}+[\mathrm{HSCFA}]_{\mathrm{end}}\right)}{\alpha \cdot \mathrm{pCO}_{2}} \cdot \frac{[\mathrm{HSCFA}]_{\text {end }}}{\left([\mathrm{SCFA}]_{\mathrm{tot}}-[\mathrm{HSCFA}]_{\mathrm{end}}\right)} \Leftrightarrow \\
& {[\mathrm{HSCFA}]_{\mathrm{end}}^{2}+\left([\mathrm{BCE}]_{\mathrm{tot}}+\alpha \cdot \mathrm{pCO}_{2}^{\text {end }} \cdot 10^{\left(\mathrm{pK}_{\mathrm{SCFA}}+\mathrm{pK}_{\mathrm{CO}_{2}}\right)}\right)} \\
& \times[\mathrm{HSCFA}]_{\mathrm{end}}+\alpha \cdot \mathrm{pCO}_{2}^{\text {end }} \cdot 10^{\left(\mathrm{pK}_{\mathrm{SCFA}}+\mathrm{pK}_{\mathrm{CO}_{2}}\right)} \cdot[\mathrm{SCFA}]_{\mathrm{tot}}=0 .
\end{aligned}
$$

This quadratic equation can be solved in the usual manner, yielding

$$
\begin{aligned}
& {[\mathrm{HSCFA}]_{\text {end }}=-\frac{\left([\mathrm{BCE}]_{\mathrm{tot}}+\alpha \cdot \mathrm{pCO}_{2}^{\mathrm{end}} \cdot 10^{\left(\mathrm{pK}_{\mathrm{SCFA}}-\mathrm{pK}_{\mathrm{CO}_{2}}\right)}\right)}{2}} \\
& \pm \sqrt{\frac{\left([\mathrm{BCE}]_{\mathrm{tot}}+\alpha \cdot \mathrm{pCO}_{2}^{\mathrm{end}} \cdot 10^{\left(\mathrm{pK}_{\mathrm{SCFA}}-\mathrm{pK}_{\mathrm{CO}_{2}}\right)}\right)^{2}}{4}}
\end{aligned}
$$

With the initial parameters from our example above,

$$
\begin{aligned}
& \mathrm{pH}_{\text {init }}=6.4, \mathrm{pCO}_{2}^{\text {init }}=70 \mathrm{kPa},[\mathrm{SCFA}]_{\mathrm{tot}}=100 \mathrm{mmol} \cdot \mathrm{L}^{-1} \\
& \Rightarrow[\mathrm{BCE}]_{\text {tot }}=29.49 \mathrm{mmol} \cdot \mathrm{L}^{-1},\left[\mathrm{H}^{+}\right]_{\text {tot }}^{\text {init }}=18.83 \mathrm{mmol} \cdot \mathrm{L}^{-1}
\end{aligned}
$$

and assuming that the $\mathrm{pCO}_{2}$ drops to

$$
\mathrm{pCO}_{2}^{\text {end }}=50 \mathrm{kPa} \text {, }
$$

we obtain

$$
[\mathrm{HSCFA}]_{\mathrm{end}}=1.80 \mathrm{mmol} \cdot \mathrm{L}^{-1},
$$

$$
\text { (from equation [A13]) }
$$

$$
\left[\mathrm{H}_{2} \mathrm{CO}_{3}\right]_{\mathrm{end}}=\alpha \cdot \mathrm{pCO}_{2}^{\mathrm{end}}=11.70 \mathrm{mmol} \cdot \mathrm{L}^{-1}
$$

(Henry's law)

$$
\left[\mathrm{SCFA}^{-}\right]_{\mathrm{end}}=[\mathrm{SCFA}]_{\mathrm{tot}}-[\mathrm{HSCFA}]_{\mathrm{end}}=98.20 \mathrm{mmol} \cdot \mathrm{L}^{-1},
$$

$$
\left[\mathrm{HCO}_{3}^{-}\right]_{\mathrm{end}}=[\mathrm{BCE}]_{\mathrm{tot}}+[\mathrm{HSCFA}]_{\mathrm{end}}=31.29 \mathrm{mmol} \cdot \mathrm{L}^{-1},
$$

$$
\begin{aligned}
& \mathrm{pH}_{\text {end }}=\mathrm{pK}_{\mathrm{SCFA}} \\
& \quad+\log _{10}\left(\left([\mathrm{SCFA}]_{\mathrm{tot}}-[\mathrm{HSCFA}]_{\text {end }}\right) /[\mathrm{HSCFA}]_{\text {end }}\right)=6.54 \\
& \\
& {[\mathrm{~A} 17]} \\
& {\left[\mathrm{H}^{+}\right]_{\text {tot }}^{\text {end }}=[\mathrm{HSCFA}]_{\text {end }}+\left[\mathrm{H}_{2} \mathrm{CO}_{3}\right]_{\text {end }}=16.44 \mathrm{mmol} \cdot \mathrm{L}^{-1} .}
\end{aligned}
$$

Note that in a real buffer solution, $\mathrm{pH}$ values will be slightly more acidic $(\Delta \mathrm{pH} \sim 0.1$ to 0.2$)$ than given by these equations due to the fact that the activity constant of the unprotonated SCFA anion is significantly lower than that of the protonated form and changes 
with the concentration of cations in a complex manner (Mortimer, 2008).

\section{Equations for the Closed Buffer System}

In a closed system, no $\mathrm{CO}_{2}$ can escape. Accordingly,

$$
\begin{aligned}
{\left[\mathrm{CO}_{2}\right]_{\text {tot }}^{\text {init }} } & =\left[\mathrm{H}_{2} \mathrm{CO}_{3}\right]_{\text {init }}+\left[\mathrm{HCO}_{3}^{-}\right]_{\text {init }} \\
& =\left[\mathrm{H}_{2} \mathrm{CO}_{3}\right]_{\text {end }}+\left[\mathrm{HCO}_{3}^{-}\right]_{\text {end }}=\left[\mathrm{CO}_{2}\right]_{\text {tot }}^{\text {end }}=\text { constant } .
\end{aligned}
$$

Again, bicarbonate excess $\left([\mathrm{BCE}]_{\mathrm{tot}}\right)$ is conserved (equation [A19]):

$$
\begin{aligned}
{\left[\mathrm{CO}_{2}\right]_{\mathrm{tot}}^{\mathrm{nit}}-\left[\mathrm{H}^{+}\right]_{\mathrm{tot}}^{\mathrm{init}} } & =\left[\mathrm{CO}_{2}\right]_{\mathrm{tot}}^{\mathrm{end}}-\left[\mathrm{H}^{+}\right]_{\mathrm{tot}}^{\text {end }} \\
& =[\mathrm{BCE}]_{\mathrm{tot}}=\text { constant }
\end{aligned}
$$

This means that because $\left[\mathrm{CO}_{2}\right]_{\text {tot }}$ is conserved, the total concentration of protons is also conserved:

$$
\left[\mathrm{H}^{+}\right]_{\mathrm{tot}}^{\mathrm{init}}=\left[\mathrm{H}^{+}\right]_{\mathrm{tot}}^{\mathrm{end}}=\text { constant }
$$

Furthermore, the isohydric principle holds (equation [A11]), so that with equation [A10], we get

$$
\begin{aligned}
& 10^{\left(\mathrm{pK}_{\mathrm{SCFA}}-\mathrm{pK}_{\mathrm{CO}_{2}}\right)}=\frac{\left[\mathrm{HCO}_{3}^{-}\right]}{\left[\mathrm{H}_{2} \mathrm{CO}_{3}\right]} \cdot \frac{[\mathrm{HSCFA}]}{\left[\mathrm{SCFA}^{-}\right]} \\
& =\frac{\left([\mathrm{BCE}]_{\mathrm{tot}}+[\mathrm{HSCFA}]_{\mathrm{end}}\right)}{\left(\left[\mathrm{H}^{+}\right]_{\mathrm{tot}}-[\mathrm{HSCFA}]_{\mathrm{end}}\right)} \cdot \frac{[\mathrm{HSCFA}]_{\mathrm{end}}}{\left([\mathrm{SCFA}]_{\mathrm{tot}}-[\mathrm{HSCFA}]_{\mathrm{end}}\right)} .
\end{aligned}
$$

This again yields a quadratic equation, the solution of which is given by

$$
\begin{aligned}
& {[\mathrm{HSCFA}]_{\text {end }}} \\
& =-1 \cdot \frac{\left([\mathrm{BCE}]_{\text {tot }}+10^{\left(\mathrm{pK}_{\mathrm{SCFA}}-\mathrm{pK}_{\mathrm{CO}_{2}}\right)} \cdot\left(\left[\mathrm{H}^{+}\right]_{\text {tot }}+[\mathrm{SCFA}]_{\mathrm{tot}}\right)\right)}{2 \cdot\left(1-10^{\left(\mathrm{pK}_{\mathrm{SCFA}^{-}}-\mathrm{pK}_{\mathrm{CO}_{2}}\right)}\right)}
\end{aligned}
$$

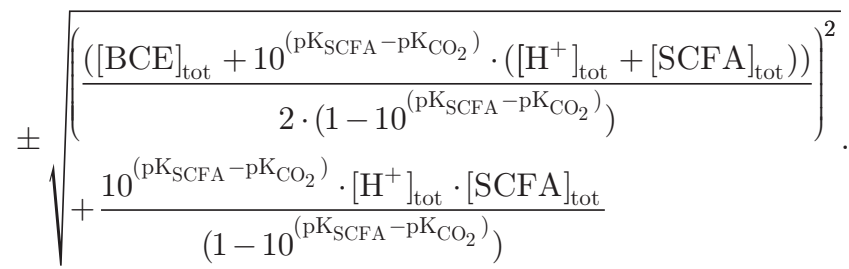

After $[\mathrm{HSCFA}]_{\text {end }}$ has been determined from equation [A21], all other parameters follow using equations [A15] to [A19] as before.

\section{Comparison of the Open and Closed Systems}

The importance of a loss of $\mathrm{CO}_{2}$ from the rumen for buffering of protons is intuitively clear, but can be rigorously proven using these equations. Let us compare the manner in which the system responds to a production of fermentational acid (HSCFA) in the open and the closed configuration. We will again assume initial values of

$\mathrm{pH}_{\text {init }}=6.4, \mathrm{pCO}_{2}^{\text {init }}=70 \mathrm{kPa},[\mathrm{SCFA}]_{\text {tot }}^{\text {init }}=100 \mathrm{mmol} \cdot \mathrm{L}^{-1}$

$\Rightarrow[\mathrm{BCE}]_{\mathrm{tot}}^{\mathrm{init}}=29.49 \mathrm{mmol} \cdot \mathrm{L}^{-1},\left[H^{+}\right]_{\mathrm{tot}}^{\mathrm{init}}=18.83 \mathrm{mmol} \cdot \mathrm{L}^{-1}$.

Assuming that an equimolar amount of SCFA and protons are generated (e.g., $20 \mathrm{mmol} \cdot \mathrm{L}^{-1}$ ), both the total concentration of SCFA and the bicarbonate excess will change according to

$$
\begin{aligned}
& {[\mathrm{SCFA}]_{\mathrm{tot}}^{\text {end }}=(100+20) \mathrm{mmol} \cdot \mathrm{L}^{-1}=120 \mathrm{mmol} \cdot \mathrm{L}^{-1}} \\
& {[\mathrm{BCE}]_{\text {tot }}^{\text {end }}=(29.49-20) \mathrm{mmol} \cdot \mathrm{L}^{-1}=9.49 \mathrm{mmol} \cdot \mathrm{L}^{-1} .}
\end{aligned}
$$

Using equations [A13] or [A21] as appropriate to determine $[\mathrm{HSCF} A]_{\text {tot }}^{\text {open }}$ and $[\mathrm{HSCFA}]_{\text {tot }}^{\text {closed }}$, respectively, equations [A15] to [A18] can be used to calculate the $\mathrm{pH}$, $\mathrm{pCO}_{2}$, and total amount of free or buffered protons in the solution, yielding

$$
\begin{aligned}
& \mathrm{pH}_{\text {end }}^{\text {open }}=6.07 \quad \Delta \mathrm{pH}_{\text {end }}^{\text {open }}=-0.33 \\
& \mathrm{pCO}_{2}^{\text {open }}=70 \mathrm{kPa} \quad \Delta \mathrm{pCO}_{2 \text { end }}^{\text {open }}=0 \mathrm{kPa} \\
& {\left[\mathrm{H}^{+}\right]_{\text {end }}^{\text {open }}=22.45 \mathrm{mmol} \cdot \mathrm{L}^{-1} \quad \Delta\left[\mathrm{H}^{+}\right]_{\text {end }}^{\text {open }}=3.62 \mathrm{mmol} \cdot \mathrm{L}^{-1}}
\end{aligned}
$$

$\mathrm{pH}_{\text {end }}^{\text {closed }}=5.89 \quad \Delta \mathrm{pH}_{\text {end }}^{\text {closed }}=-0.52$

$\mathrm{pCO}_{2}$ end $=129 \mathrm{kPa} \quad \Delta \mathrm{pCO}_{2 \text { end }}^{\text {closed }}=59 \mathrm{kPa}$

$\left[\mathrm{H}^{+}\right]_{\text {end }}^{\text {closed }}=39.32 \mathrm{mmol} \cdot \mathrm{L}^{-1} \quad \Delta\left[\mathrm{H}^{+}\right]_{\text {end }}^{\text {closed }}=20.49 \mathrm{mmol} \cdot \mathrm{L}^{-1}$.

Accordingly, the amount of $\left[\mathrm{HCO}_{3}^{-}\right]$that is required to restore the initial $\mathrm{pH}$ of 6.4 is much higher in the closed system than in the open system:

$$
\begin{array}{ll}
\Delta\left[\mathrm{HCO}_{3}^{-}\right]_{\text {added }}^{\text {open }}=20 \mathrm{mmol} \cdot \mathrm{L}^{-1} & \mathrm{pCO}_{2 \text { after addition }}^{\text {open }}=70 \mathrm{kPa} \\
\Delta\left[\mathrm{HCO}_{3}^{-}\right]_{\text {added }}^{\text {closed }}=59 \mathrm{mmol} \cdot \mathrm{L}^{-1} & \mathrm{pCO}_{2 \text { after addition }}^{\text {closed }}=155 \mathrm{kPa} .
\end{array}
$$

\section{Calculating Base Excess}

Using these equations, it is also possible to estimate the theoretical base excess $\mathrm{BE}_{6.4}$ and $\mathrm{BE}_{5.8}$ of samples as defined in the experimental part of this study by varying $\left[\mathrm{H}^{+}\right]_{\text {tot }}$. Assuming conditions of 
$\mathrm{pH}_{\text {init }}=6.55$ (mean $\mathrm{pH}$ of hay/silage-fed animals), $\mathrm{pCO}_{2}^{\text {init }}=70 \mathrm{kPa}$ (assumed, rumen),

$[\mathrm{SCFA}]_{\mathrm{tot}}^{\text {init }}=80 \mathrm{mmol} \cdot \mathrm{L}^{-1}($ mean measured value of hay/silage-fed animals),

$\mathrm{pCO}_{2}^{\text {end }}=100 \mathrm{kPa}$ (measurement of sample in laboratory),

$\left[\mathrm{H}^{+}\right]_{\text {tot }}$ has to be increased by 0.5 and $39.5 \mathrm{mmol} \cdot \mathrm{L}^{-1}$ to shift $\mathrm{pH}_{\text {end }}$ to 6.4 and 5.8, respectively, in the mathematical model. These values are in surprisingly good agreement with the experimental values of $0.5 \pm 3$ $\mathrm{mmol} \cdot \mathrm{L}^{-1}\left(\mathrm{BE}_{(6.4)}\right)$ and $39.2 \pm 2.8\left(\mathrm{BE}_{(5.8)}\right)$ in this study for the hay/silage-fed group of animals. In conjunction with the good fits obtained for the buffer capacity, this suggests that the model presented here with SCFA and $\mathrm{HCO}_{3}{ }^{-}$as the major buffers adequately describes the buffering situation in the hay/silage-fed animals.

Assuming conditions reflecting the means found in the concentrate/silage-fed animals of
$\mathrm{pH}_{\mathrm{init}}=5.52$ (mean $\mathrm{pH}$ of concentrate/silage-fed animals), $\mathrm{pCO}_{2}^{\text {init }}=70 \mathrm{kPa}$ (assumed, rumen),

$[\mathrm{SCFA}]_{\mathrm{tot}}^{\text {init }}=89 \mathrm{mmol} \cdot \mathrm{L}^{-1}$ (mean measured value of concentrate/silage-fed animals),

$\mathrm{pCO}_{2}^{\text {end }}=100 \mathrm{kPa}$ (measurement of sample in laboratory)

$\left[\mathrm{H}^{+}\right]_{\text {tot }}$ has to be decreased, corresponding to an addition of a strong base. This approach yields values of -52 and $-12.6 \mathrm{mmol} \cdot \mathrm{L}^{-1}$ for a $\mathrm{pH}_{\text {end }}$ of 6.4 and 5.8 , respectively. These values deviate quantitatively from the means obtained experimentally in these samples, namely $\mathrm{BE}{ }_{(6.4)}=-93 \pm 18.5 \mathrm{mmol} \cdot \mathrm{L}^{-1}$ and $\mathrm{BE}_{(5.8)}=$ $-22.2 \pm 13.8 \mathrm{mmol} \cdot \mathrm{L}^{-1}$. It appears likely that other buffers than SCFA and bicarbonate are involved in buffering the $\mathrm{pH}$ of the rumen in this group of animals and that the total amount of bound protons found intraruminally is significantly higher than the $\mathrm{pH}$ might suggest. 